\title{
A INFLUÊNCIA DOS TRATADOS AMBIENTAIS MULTILATERAIS RELATIVOS AO CLIMA NA EFETIVIDADE DO DIREITO AMBIENTAL NO BRASIL
}

\author{
THE INFLUENCE OF MULTILATERAL ENVIRONMENTAL TREATIES RELATED \\ TO CLIMATE IN THE EFFECTIVENESS OF ENVIRONMENTAL LAW IN BRAZIL
}

\author{
LA INFLUENCIA DE LOS TRATADOS AMBIENTALES MULTILATERALES \\ RELATIVOS AL CLIMA EN LA EFECTIVIDAD DEL DERECHO AMBIENTAL EN \\ BRASIL
}

\section{LAUREN LAUTENSCHLAGER}

https://orcid.org/0000-0003-0681-3865 / http://lattes.cnpq.br/5590099799258771 / lauren.lauten@gmail.com

Doutora em Direito pelo Centro Universitário de Brasília. Professora da Faculdade Sul Americana (FASAM). Brasília, DF, Brasil.

MARCELo Dias VARELLA

https://orcid.org/0000-0001-5538-0838 / http://lattes.cnpq.br/2150240733840094 / marcelodvarella@gmail.com

Professor do Programa de Mestrado e Doutorado em Direito do UNICEUB. Doutor em Direito pela Universidade de Paris. Livre-Docente pela USP. Pesquisador nível 1 do CNPq. Brasília, DF, Brasil.

\section{RESUMO}

O presente artigo tem por objetivo analisar a relação entre o conteúdo dos tratados ambientais multilaterais relativos ao clima ratificados pelo Brasil e as políticas públicas por este realizadas. Parte-se da hipótese de que quanto mais específico o tratado nas obrigações a serem atingidas, quanto maiores os esforços e as conquistas dos negociadores internacionais em realizar um texto mais consistente, maior e mais efetiva é a produção normativa-institucional brasileira no mesmo tema. Para tanto, a análise é feita por meio de uma matriz de análise composta por critérios de efetividade, os quais são aplicados tanto nos tratados, quanto nas normas e instituições criadas pelo governo brasileiro. Conclui-se que os textos ambientais internacionais ratificados pelo Brasil exercem grande influência nas políticas públicas ambientais brasileiras, exigindo uma similitude na aplicação positiva dos critérios, pois somente dessa forma o direito brasileiro poderá tornar o tratado ambiental responsivo no plano doméstico.

Palavras-chave: Clima; Efetividade; Proteção Ambiental.

\section{ABSTRACT}

This article aims to analyze the relationship between the content of the multilateral environmental treaties related to the climate ratified by Brazil and the public policies carried out. Our hypothesis is that the more specific the treaty is in its obligations and the greater are the efforts of international negotiators to write a more consistent text, the greater and more effective is the normative-institutional Brazilian production on the same subject. A matrix was constructed for analysis composed by criteria of effectiveness that will be applied both in the treaties, norms and institutions created by the Brazilian government. It is concluded that the international environmental texts ratified by Brazil exert a great influence on the Brazilian public environmental policies, demanding a similitude in the positive application of the criteria, because only in this way Brazilian law can make the environmental treaty effective in the domestic plane. 
Keywords: Climate; Effectiveness; Environmental Protection.

\section{RESUMEN}

El presente artículo tiene por objetivo analizar la relación entre el contenido de los tratados ambientales multilaterales relativos al clima ratificados por Brasil y las políticas públicas realizadas por el país. La hipótesis de partida es de que cuanto más específico el tratado en las obligaciones impuestas, cuanto más altos los esfuerzos y las conquistas de los negociadores internacionales en redactar un texto más consistente, mayor y más efectiva es la producción normativa-institucional brasileña sobre el mismo tema. A estos efectos, el análisis es implementado por medio de una matriz de análisis compuesta por criterios de efectividad que son aplicados tanto en los tratados, como también sobre las normas e instituciones creadas por el gobierno brasileño. Se puede concluir que los textos ambientales internacionales ratificados por Brasil ejercen gran influencia en las políticas públicas ambientales del país, exigiendo una similitud en la aplicación positiva de los créditos, una vez que únicamente de esta forma el derecho brasileño logrará tornar el tratado ambiental responsivo a nivel doméstico.

Palabras clave: Clima; Efectividad; Protección Ambiental.

\section{SUMÁRIO}

INTRODUÇÃO; 1 MATRIZ DE ANÁLISE; 2 CONJUNTO NORMATIVO-INSTITUCIONAL; 2.1 Camada de Ozônio; 2.2 Mudanças climáticas; 3 DESCRIÇÃO DOS RESULTADOS COM A APLICAÇÃO DOS CRITÉRIOS DE EFETIVIDADE; 3.1 Camada de Ozônio; 3.2 Mudanças climáticas; CONCLUSÃO; REFERÊNCIAS

\section{INTRODUÇÃO}

A sobre-exploração dos recursos naturais e a degradação do ambiente natural levaram à crise ambiental ${ }^{1}$ surgida como consequência da sociedade da segunda modernidade ${ }^{2}$, exigindo que a questão de proteção ambiental fosse posta como um ponto de sobrevivência ${ }^{3}$.

$\mathrm{Na}$ medida em que a proteção ambiental foi inserida na sociedade, tornando todos reféns de condições ambientais ${ }^{4}$, a elaboração de normas com valor ambiental passou a ser a forma que o Estado regulador interveio para proteger o meio ambiente ${ }^{5}$. Essa junção de novos

\footnotetext{
1 AYALA, P. A. Direito e incerteza: a proteção jurídica das futuras gerações no Estado de direito ambiental. Florianópolis: UFSC, 2002. Dissertação (Mestrado em Direito), Universidade Federal de Santa Catarina, Florianópolis, 2002.

2 BECK, U. La sociedad del riesgo global. Madrid: Siglo Veintiuno, 2002. apud LEFF, E. Complexidade, Racionalidade Ambiental e Diálogo de Saberes. In: Revista Educação e Realidade, v. 34, n. 3, p. 17-24, set./dez. 2009.

3 MALJEAN-DUBOIS, S. International environmental law. In: Seminário Jurídico Avançado, UNICEUB, Brasília, 2014.

${ }^{4}$ FENSTERSEIFER, T. Direitos fundamentais e proteção do ambiente: a dimensão ecológica da dignidade humana no marco jurídico-constitucional do Estado Socioambiental de Direito. Porto Alegre: Livraria do Advogado, 2008. p. 108. Nesse mesmo sentido, NASSER, S. H. Direito internacional do meio ambiente, direito transformado, jus cogens e soft law. In: NASSER, S. H.; REI, F. (Org.). Direito internacional do meio ambiente. São Paulo: Atlas, 2006. p. 19-30.

${ }^{5}$ Conforme menciona BENJAMIN, A. H. V. O Estado teatral e a implementação do direito ambiental. BDJur, Brasília, DF, 2010. Nesse sentido, SOARES, G. F. S. Curso de direito internacional público. São Paulo: Atlas, 2004 e LEITE, J. R. M. L. Sociedade de risco e Estado. In: CANOTILHO, J. J. C.; LEITE, J. R. M. Direito Constitucional ambiental brasileiro. 5. ed. São Paulo: Saraiva, 2012. p. 157-232.
} 
valores e novas normas constitui o que se denomina Estado Socioambiental de Direito ${ }^{6}$, sendo neste que o presente estudo contextualiza-se.

O direito ambiental é uma disciplina jurídica de resultado. Todavia, necessita para ser efetivo da interdisciplinaridade, seja em relação ao que se pode compreender e como mensurar a efetividade, seja com o auxílio da teoria dos regimes ${ }^{7}$, seja ainda com a aproximação do direito com as políticas públicas. Além disso, ele possibilita que qualquer investigação ocorra de forma interna e internacional. Dessa forma, dois sub-ramos do direito são abordados, com todas as suas complexidades inerentes e inter-relações necessárias ${ }^{8}$ : o direito internacional ambiental e o direito ambiental doméstico. Trabalha-se, assim, com a ideia tanto de internacionalização ${ }^{9}$, como com a ideia de internalização.

Há relação direta entre a efetividade ${ }^{10}$ da proteção ambiental brasileira e o conteúdo dos tratados ambientais multilaterais. Quanto mais específico o tratado nas obrigações a serem atingidas, quanto maiores os esforços e as conquistas dos negociadores internacionais em realizar um texto mais consistente, maior e mais efetiva é a produção normativa brasileira no mesmo tema. Tal relação pode ser observada tanto com a criação de normas e instituições criadas em decorrência dos documentos internacionais firmados, como pelo resultado da aplicação dos critérios de efetividade. E isso se torna ainda mais evidente com a nova abordagem estabelecida no Acordo de Paris, onde as políticas públicas criadas no direito doméstico servirão de diagnóstico e prognóstico. Porém, exigir que os países façam as suas

${ }^{6}$ CANOTILHO, J. J. G. Estado constitucional ecológico e democracia sustentada. In: LEITE, José Rubens Morato; FERREIRA, Heline Silvini; BORATTI, Larissa Verri (Org.). Estado de direito ambiental: tendências. 2. ed. Rio de Janeiro: Forense Universitária, 2010. p. 31-34. e LEITE, J. R. M.; CAETANO, M. A. Estado de direito ambiental e complexidade. In: PERALTA, Carlos E.; ALVARENGA, Luciano J.; AUGUSTIN, Sérgio (Org.). Direito e justiça ambiental: diálogos interdisciplinares sobre a crise ecológica. Caxias do Sul: Educs, 2014. p. 139-160.

7 YOUNG, O. R. Teoria do regime e a busca de governança global. In: VARELLA, Marcelo D.; BARROSPLATIAU, Ana Flavia (Org.). Proteção internacional do meio ambiente. Brasília: UNITAR, UNICEUB, UNB, 2009. v. 4. p. 220-235. Conforme BIRNIE, P.; BOYLE, A. International Law and the environment. 2. ed. [S.l.]: Oxford, 1994.

8 MORRISON, F. L. The relationship of international, regional, and national environmental law. In: MORRISON, F. L., WOLFRUM, R. (Ed.). International, Regional, and National Environmental Law. Kluwer Law International. [S.l.]: Springer, 2000. p. 113-132. Em sentido semelhante, WOLFRUM, R. The convention on biological diversity: using state jurisdiction as a means of ensuring compliance. In: WOLFRUM, R. (Ed.). Enforcing environmental standards: Economic mechanisms as viable means? [S.l.]: Springer, 1996. p. 374-393.

9 VARELLA, M. D. Internacionalização do Direito: direito internacional, globalização e complexidade. Brasília: UniCEUB, 2013.

10 OST, F. Legal system between order and disorder. [S.I.]: Oxford University Press, 1994. e KOSKENNIEMI, M. From apology to utopia. The structure of international legal argument. Cambridge: Cambridge University Press, 2006. 
contribuições de acordo com as suas capacidades ${ }^{11}$ não deve significar a permissão de suavidade, vagueza ou abertura nas normas que compõem os tratados.

O objeto deste estudo é analisar a relação entre o conteúdo dos tratados ambientais multilaterais relativos ao clima ratificados pelo Brasil e as políticas públicas por este realizadas. Para isso, é estruturada e aplicada uma matriz de análise composta por critérios de efetividade.

Assim, o presente artigo além desta e da conclusão é dividido em três partes. $\mathrm{Na}$ primeira, é explicada a matriz de análise. Na segunda, o conjunto de normas e instituições a ser objeto de aplicação da matriz é delimitado. Por fim, na terceira ocorre a descrição dos resultados com a aplicação dos critérios.

\section{MATRIZ DE ANÁLISE}

A fim de analisar a relação entre o conteúdo dos tratados ambientais multilaterais ratificados pelo Brasil e relativos ao clima, construiu-se uma matriz composta por critérios de efetividade no âmbito global, os quais foram divididos entre materiais e formais, que serão aplicados nos tratados ambientais multilaterais, bem como critérios de efetividade no âmbito nacional, os quais foram divididos entre normativos e institucionais, que serão aplicados nas normas e instituições criadas pelo governo brasileiro.

No âmbito global, em relação aos aspectos materiais, um tratado ambiental terá mais chances de ser efetivo se ele: (a) assegurar a proteção ambiental; (b) conduzir à modificação no comportamento humano; (c) tiver impacto só por meio de sua própria existência; (d) possuir clareza no conteúdo das obrigações; e (e) dispor de metas e métodos. Já em relação aos aspectos formais, um tratado ambiental será considerado efetivo para a presente análise na medida em que ele: (a) tiver entrado em vigor em tempo razoável; (b) contiver formas de garantir a conformidade; e (c) contiver meios para promover o cumprimento.

A escolha dos critérios no âmbito nacional utilizou alguns critérios estabelecidos no âmbito global, mas também substituiu e incluiu outros. As normas feitas pelo Brasil serão efetivas se: (a) tiverem entrado em vigor em tempo razoável; (b) corresponderem com os

11 Sobre o assunto, OLIVEIRA, A. S. Tratamento diferenciado dos países em desenvolvimento e mudanças climáticas: perspectivas a partir do Acordo de Paris. 2017. Tese (Doutorado em Direito) Faculdade de Direito da Universidade Federal do Rio Grande do Sul, Porto Alegre, 2017, menciona que o tratamento diferenciado dos países em desenvolvimento deve ganhar novos contornos, mas não pode ter seu significado esvaziado como ocorreu no Acordo de Paris. 
A INFLUÊNCIA DOS TRATADOS AMBIENTAIS MULTILATERAIS RELATIVOS AO CLIMA NA EFETIVIDADE DO DIREITO AMBIENTAL NO BRASIL

LAUREN LAUTENSCHLAGER MARCELO DIAS VARELLA

objetivos do tratado ambiental; (c) possuírem clareza no conteúdo das obrigações; (d) disporem de metas e métodos; (e) forem completas, com todas as normas necessárias; (f) conduzirem a modificação no comportamento humano; (g) tiverem impacto só por meio de sua própria existência; (h) contiverem formas de garantir a conformidade; e (i) contiverem meios para promover o cumprimento. As instituições serão consideradas efetivas se: (a) forem criadas em tempo razoável; (b) corresponderem com o objetivo das normas criadas; (c) forem completas, com todos os órgãos necessários; e (d) tiverem vitalidade institucional. Alguns desses critérios são os mesmos a serem analisados nos arranjos normativos, apenas contextualizados com os arranjos institucionais.

É importante mencionar que a escolha de critérios deve ser acompanhada pela forma apropriada de lê-los. Assim, para tornar o trabalho mais objetivo, os critérios foram exaustivamente trabalhados em estudo específico ${ }^{12}$.

Além disso, a aplicação de tais critérios ocorre em diferentes tipos de normas, uma vez que, normativamente, no âmbito internacional, existem Convenções, Protocolos e Acordos. Já no âmbito interno, as normas foram divididas em normas internalizantes ${ }^{13}$, específicas ${ }^{14}$ e exequentes $^{15} \mathrm{e}$, institucionalmente, no âmbito interno, existem diferentes órgãos como secretarias, departamentos e grupos de trabalho. Por fim, os critérios que compõem a matriz serão interpretados como de aplicação/observação positiva, como de aplicação/observação negativa, como de aplicação/observação parcial, ou ainda, como não aplicados. Todas as normas e instituições a serem analisadas relacionam-se diretamente com os documentos internacionais firmados e se encontram em vigor.

\footnotetext{
12 VARELLA, M. D.; LAUTENSCHLAGER, L. Critérios de Efetividade na Proteção Ambiental. In: Revista do Programa de Pós-Graduação em Direito da UFC, v. 36.1, p. 295-329, jan./jun. 2016.

13 As normas internalizantes referem-se a decretos legislativos e decretos executivos que possuem como finalidade apenas aprovar e promulgar (ou seja, internalizar) os documentos internacionais, fazendo-os valer em território nacional. Como as normas internalizantes trazem apenas a aprovação e/ou promulgação dos documentos internacionais, os únicos critérios que serão aplicados a esse conjunto inicial de normas terão validade se: a) tiverem entrado em vigor em tempo razoável; b) corresponderem aos objetivos do tratado ambiental; c) conduzirem a modificação no comportamento humano; e d) tiverem impacto só por meio de sua própria existência. 0 teor dessas normas não traz nenhuma obrigação, meta, compliance nem enforcement. Além disso, não exige nenhuma normatização posterior.

${ }^{14}$ As normas específicas referem-se aos atos legislativos primários específicos ao tema objeto no tratado ambiental.

15 As normas exequentes referem-se aos atos legislativos subsequentes que buscam executar 0 ato legislativo primário. Fazem parte desse último conjunto, Decretos não numerados, Resoluções, Instruções Normativas e Portaria dos órgãos ambientais.
} 


\section{CONJUNTO NORMATIVO-INSTITUCIONAL}

Para que seja possível a aplicação da matriz, é necessário primeiro delimitar o conjunto de normas e instituições que serão objeto desta, seja no âmbito internacional, seja ainda no âmbito interno nas duas áreas que compõem o regime do clima: camada de Ozônio e mudanças climáticas.

\subsection{Camada de Ozônio}

Os documentos internacionais que se referem à Camada de Ozônio são a Convenção de Viena sobre a proteção da Camada de Ozônio de 1985, e o seu protocolo correspondente, o Protocolo de Montreal em $1987^{16}$.

Após constatações de que a diminuição do Ozônio estaria ocorrendo não apenas como consequência de um fenômeno natural, documentos internacionais foram firmados a fim de obter uma redução no consumo das substâncias que destroem a Camada de Ozônio (SDCO) até a sua total eliminação. Em que pese vários tenham sido os motivos implícitos que levaram a assinatura de tais documentos ${ }^{17}$, é necessário mencionar que o Protocolo obteve sucesso ${ }^{18}$.

Em âmbito nacional, algumas particularidades em relação às substâncias que destroem a camada de Ozônio merecem ser destacadas. A primeira delas é que, até o ano de 1995, o Brasil era o país líder no consumo de CFCs na América Latina e o segundo maior consumidor da substância no grupo dos países em desenvolvimento, ficando atrás apenas da China ${ }^{19}$. Outra particularidade decorre do cumprimento antecipado, pelo Brasil, das metas estipuladas no

\footnotetext{
${ }^{16}$ Esse Protocolo foi sendo aperfeiçoado por meio de emendas, tendo sido a última aprovada em outubro de 2016 via Acordo de Kigali.

17 SUNSTEIN, C. R. Montreal versus Kyoto: a tale of two protocols. John M. Olin Law \& Economics Working Paper $\mathrm{n}^{\circ} 302$ (2d series) and Public Law and Legal Theory Working Paper $\mathrm{n}^{\circ} 136$. Working Paper $\mathrm{n}^{\circ}$ 06-17. Chicago, 2006. e GAREAU, B. J. A critical review of the successful CFC phase-out versus the delayed methyl bromide phase-out in the Montreal Protocol. In: International Environmental Agreements: Politics, Law and Economics, v. 10, n. 3, p. 209-231, 2010. e COLE, D. H. Climate Change and Collection Action. 2007. Disponível em: <http://papers.ssrn.com/sol3/papers.cfm?abstract_id=1069906>. Acesso em: 5 jan. 2016. e BRYK, D. S. The Montreal Protocol and Recent Developments to Protect the Ozone Layer. In: Environmental Law Review, v. 15, p. 275, 1991.

18 GAREAU, B. J. A critical review of the successful CFC phase-out versus the delayed methyl bromide phase-out in the Montreal Protocol. In: International Environmental Agreements: Politics, Law and Economics, v. 10, n. 3, p. 209-231, 2010.

${ }^{19}$ MINISTÉRIO DO MEIO AMBIENTE. Ações brasileiras para a proteção da camada de Ozônio. Brasília: [S.n.], 2014.
} 
A INFLUÊNCIA DOS TRATADOS AMBIENTAIS MULTILATERAIS RELATIVOS AO CLIMA NA EFETIVIDADE DO DIREITO AMBIENTAL NO BRASIL

LAUREN LAUTENSCHLAGER MARCELO DIAS VARELLA

Protocolo de Montreal ${ }^{20}$. Por fim, as primeiras ações de restrição às SDOs no Brasil ocorreram no âmbito da Secretaria Nacional de Vigilância Sanitária do Ministério da Saúde e não no âmbito do Ministério do Meio Ambiente ${ }^{21}$.

O regime relativo às substâncias que destroem a camada de Ozônio possui como normas internalizantes: o Decreto legislativo $n^{\circ} 91 / 89$ e o Decreto $n^{\circ} 99.280 / 90$, o Decreto legislativo $n^{\circ}$ 32/92 e o Decreto $n^{\circ} 2.699 / 98$, o Decreto legislativo $n^{\circ} 51 / 96$ e o Decreto $n^{\circ} 2.679 / 98$ e o Decreto legislativo $n^{\circ} 212 / 04$ e o Decreto $n^{\circ} 5.280 / 04$.

Além de analisar o texto das normas, verificou-se o texto contido na exposição de motivos dessas. Em relação a eles, dois grupos podem ser identificados. 0 primeiro grupo de exposições de motivos dispõe, de forma geral, sobre os compromissos internacionais assumidos, contextualiza o que já foi feito pelo governo brasileiro, o teor do documento internacional firmado, menciona as consultas já realizadas e destaca a importância para os diversos setores do Brasil $^{22}$. O segundo grupo de exposições de motivos refere que os documentos apenas vão complementar as formalidades legais necessárias para a execução dos atos internacionais ${ }^{23}$.

Não existem normas específicas no regime relativo às substâncias que destroem a Camada de Ozônio, porém as normas exequentes são: Portaria n 534/88, Portaria n 647/89, ambas elaboradas pela SNVS, Portaria IBAMA $n^{\circ} 29 / 95$, Resolução $n^{\circ} 267 / 00$, Resolução $n^{\circ}$

20 O que só foi possível em face do Fundo Multilateral para a Implementação do Protocolo de Montreal criado em 1990 exigindo do Brasil a elaboração de programas ou planos de ação: (1) Programa Brasileiro de Eliminação da Produção e do Consumo das Substâncias que Destroem a Camada de Ozônio (PBCO), (2) Plano Nacional de Eliminação de CFCs (PNC), (3) Programa Brasileiro de Eliminação dos HCFCs (PBH), (4) Programa Nacional de Eliminação do Brometo de Metila na Floricultura.

${ }^{21}$ MILARÉ, E. Direito do ambiente: a gestão ambiental em foco. 5. ed. São Paulo: Revista dos Tribunais, 2007.

22 Fazem parte deste grupo: 1) a exposição de motivos $n^{\circ}$ 010/98 referente ao Decreto Legislativo $n^{\circ} 91 / 89$ que destaca que o Itamaraty participou nas discussões, procedendo, logo após a adoção do Protocolo de Montreal, a uma série de consultas junto aos órgãos técnicos da Administração pública afetos à matéria e que após estas o MRI opinou pela adesão aos instrumentos internacionais, enfatizando a repercussão internacional da participação brasileira; 2) a exposição de motivos $n^{\circ} 476 / 91$ referente ao Decreto Legislativo $n^{\circ} 32 / 92$ referente à Emenda de Londres que menciona que os ajustes e as emendas adotados atenderam aos seus principais interesses e reinvindicações; 3 ) a exposição de motivos $n^{\circ}$ 440/93 referente ao Decreto Legislativo $n^{\circ}$ 51/96 que menciona que o Brasil não produz HBFC e não há dados estatísticos de sua utilização no país, porém a indústria de refrigeração utiliza-a; o brometo de metila é utilizado na agricultura e na fumigação de porões de navios e embora, no Brasil, o uso de tal substância não seja intenso é necessário iniciar trabalho de conscientização para a necessidade de se buscarem tecnologias alternativas, com vistas à redução da sua utilização; 4) a exposição de motivos $n^{\circ} 261 / 02$ referente ao Decreto Legislativo $n^{\circ}$ 212/04 expressa que o Brasil é um dos maiores consumidores de SDOs, mas logrou em alguns setores superar as metas do Protocolo.

${ }^{23}$ Fazem parte deste grupo: a exposição de motivos $n^{\circ}$ não identificado/90 referente ao Decreto $n^{\circ}$ 99.280/90; $n^{\circ} 293 / 98$ referente ao Decreto $n^{\circ} 2.699 / 98 ; n^{\circ} 273 / 98$ referente ao Decreto $n^{\circ} 2.679 / 98$ e $n^{\circ}$ $332 / 04$ referente ao Decreto $n^{\circ} 5.280 / 04$, as quais apenas mencionaram que os documentos complementarão as formalidades legais necessárias para execução dos atos internacionais. 
340/03, ambas do CONAMA, a Instrução Normativa $\mathrm{n}^{\circ}$ 01/02 elaborada conjuntamente pelo Secretário de Defesa Agropecuária do Ministério da Agricultura, Pecuária e Abastecimento, pelo Diretor Presidente da Agência Nacional de Vigilância Sanitária e pelo Presidente do Instituto Brasileiro do Meio Ambiente e dos Recursos Naturais Renováveis, as Instruções Normativas $n^{\circ}$ 37/04, $n^{\circ}$ 207/08 e a $n^{\circ} 14 / 12$ todas elaboradas pelo IBAMA, e a Portaria de $n^{\circ} 212 / 12$, elaborada pelo Ministério do Meio Ambiente - MMA.

As instituições que atuam na proteção das substâncias que destroem a camada de Ozônio são: o Comitê Executivo Interministerial - $\mathrm{PROZON}^{24}$ e o Grupo de trabalho HCFCs ${ }^{25}$.

\subsection{Mudanças climáticas}

No âmbito internacional, a temática das mudanças climáticas é marcada pela Convenção-Quadro das Nações Unidas sobre mudança climática em 1992 e pelos seus protocolos correspondentes, o Protocolo de Quioto em 1997 e o Acordo de Paris em 2015.

Quando se percebem os debates ocorridos em torno das mudanças climáticas, é nítida a inversão das posições dos países, bem como a realização de políticas internas e internacionais quando comparada em torno da Camada de Ozônio ${ }^{26}$.

Considerado como uma conquista histórica na diplomacia multilateral, já que novos caminhos no cenário da política internacional foram abertos ${ }^{27}$, o Acordo de Paris $^{28}$, em que pese $\operatorname{tardio}^{29}$, não foi feito em substituição ao Protocolo de Quioto.

24 O PROZON foi criado em 1995, via Decreto não numerado de 19/09, alterado pelo Decreto não numerado de 16/12/97 e, posteriormente, revogado por um Decreto não numerado de 06/03/03. Acredita-se que o PROZON, na verdade, deu continuidade às atividades realizadas pelo antigo e extinto Grupo de Trabalho Interministerial - GTO criado em 1991, pela Portaria IN n 929 . Esse grupo teve vigência de três anos, consoante o primeiro período de aplicação dos recursos do Fundo Multilateral do Protocolo de Montreal. As únicas diferenças que podem ser observadas entre o extinto grupo e o atual Comitê são a composição dos Ministérios, além da sua coordenação.

25 Dentro da nova estrutura do MMA, estabelecida pelo Decreto $n^{\circ} 8.975 / 17$, existe a Secretaria de Mudança do Clima e Florestas e nesta foi criado o Grupo de trabalho HCFCs pela Portaria MMA n ${ }^{\circ} 41 / 10$ com duração de quatro anos. A Portaria $n^{\circ} 179 / 15$ recriou o GT-HCFCs, estabelecendo novo prazo de vigência até $31 / 12 / 20$. A sua composição foi definida conforme a Portaria $n^{\circ} 197 / 15$.

26 PALMER, G. The Implications of Climate Change for International Law Institutions. Transnat'l L. \& Contemp. Probs., v. 2, p. 205, 1992.

${ }^{27}$ FALKNER, R. The Paris Agreement and the new logic of international climate politics. In: International Affairs, v. 92, n. 5, p. 1107-1125, 2016.

${ }^{28}$ RAJAMANI, L. Ambition and differentiation in the 2015 Paris Agreement: Interpretative possibilities and underlying politics. In: International and Comparative Law Quarterly, v. 65, n. 2, p. 493-514, 2016.

29 LEWIS, S. L. The Paris Agreement has solved a troubling problem. In: Nature, v. 532, n. 7599, p. 283, 2016. 
A INFLUÊNCIA DOS TRATADOS AMBIENTAIS MULTILATERAIS RELATIVOS AO CLIMA NA EFETIVIDADE DO DIREITO AMBIENTAL NO BRASIL

LAUREN LAUTENSCHLAGER MARCELO DIAS VARELLA

Na seara internacional, a posição brasileira sobre mudanças climáticas sofreu mudanças consideráveis entre 1972 e $1990^{30}$. No âmbito interno, na década de 1990, as emissões de GEE foram influenciadas pela busca de políticas econômicas neoliberais e, posteriormente, pela redução da inflação. Além disso, o crescimento em alguns setores e a expansão do comércio global do país provocou a aceleração das taxas de desmatamento, o que perdurou até o ano de $2004^{31}$. Apenas entre os anos de 2005 e 2010 o Brasil reduziu as suas taxas de emissão em face de uma queda no desmatamento amazônico ${ }^{32}$.

As mudanças climáticas possuem como normas internalizantes os Decretos Legislativos $n^{\circ} 1 / 94$ e $n^{\circ} 144 / 02$ e os Decretos $n^{\circ} 2.652 / 98$ e $n^{\circ} 5.445 / 05$. Da mesma forma que foi feito com as normas relacionadas à Camada de Ozônio, verificou-se o texto contido na exposição de motivos delas ${ }^{33}$.

Como normas específicas, podem ser citadas a Lei $n^{\circ} 12.187 / 09$ e a Lei $n^{\circ} 12.114 / 09$ e suas exposições de motivos ${ }^{34}$. As normas exequentes relativas às mudanças climáticas são: 0 Decreto $n^{\circ} 7.343 / 10$, o Decreto $n^{\circ} 7.390 / 10$, a IN $n^{\circ} 12 / 10$ do IBAMA ${ }^{35}$.

${ }^{30}$ VIOLA, E. $O$ regime internacional de mudança climática e o Brasil. In: RBCS, v. 17, n. 50, p. 25-179, out. 2002.

31 VIOLA, E.; FRANCHINI, M. Climate Politics in Brazil: Public awareness, social transformations and emissions reduction. In: BAILEY, lan; COMPSTON, Hugh (Ed.). Feeling the heat: The politics of climate policy in rapidly industrializing countries, 2012. p. 253-291.

32 VIOLA, E. Evolução da mudança climática na agenda internacional e transição para uma economia de baixo carbono, 1990-2009. In: LEITE, J. R. M.; FERREIRA, H. S.; BORATTI, L. V. (Org.). Estado de direito ambiental: tendências. 2.ed. Rio de Janeiro: Forense Universitária, 2010. p. 47-94.

${ }^{33}$ A exposição de motivos $n^{\circ}$ 068/93 referente ao Decreto Legislativo $n^{\circ}$ 01/94 menciona que a Resolução $n^{\circ} 45 / 22$ foi aprovada, dando ênfase à participação brasileira. Conforme consta na exposição, o Brasil tem se colocado na primeira linha de combate dos problemas globais. Além disso, dadas sua extensão territorial, população e complexidade econômica, é vítima potencial do "efeito estufa", embora seja modesto contribuinte para o problema. A exposição de motivos $n^{\circ}$ 039/02 referente ao Decreto Legislativo $\mathrm{n}^{\circ} 144 / 02$, por sua vez reconheceu a necessidade de um protocolo com compromissos mais claros e profundos. A exposição de motivo $n^{\circ} 244 / 98$ referente ao Decreto $n^{\circ} 2.652 / 98$ e a exposição de motivos $n^{\circ}$ $115 / 05$ referente $\mathrm{n}^{\circ} 5.445 / 05$ apenas indicam que tais diplomas virão completar as formalidades necessárias à execução dos atos internacionais.

${ }^{34}$ A exposição de motivos da Lei $n^{\circ} 12.187 / 09$ refere os documentos internacionais já realizados que se relacionam à matéria e contextualiza os problemas ambientais brasileiros, dando ênfase ao aumento da ocorrência de inundações, secas e de fenômenos como o furacão "Catarina", que atingiu a costa sul do Brasil, os índices de desmatamento e queimadas, notadamente na Amazônia brasileira, e o aumento da queima de combustíveis fósseis. A exposição de motivos $n^{\circ}$ 57/08 referente à Lei $n^{\circ} 12.114 / 09$ além de sugerir modificação da Lei no 9.478/97 (Lei do Petróleo), salienta a necessária conjunção de esforços e convergência entre as propostas do Poder Executivo e do Legislativo, uma vez que o último também já teria apresentado projetos de lei com objetivo similar. Por fim, destaca que no que se refere à mudança do clima que os custos associados à inação podem ser altos.

35 De acordo com o MMA, não existe exposição de motivos referentes ao Decreto $n^{\circ} 7.390 / 10$ e a exposição de motivos da IN aparece nos "considerandos", os quais mencionam os documentos internacionais e internos feitos em relação à temática. A exposição de motivos $n^{\circ} 47 / 10$ referente ao Decreto $n^{\circ} 7.343 / 10$ apenas trata do teor dele, ou seja, a estruturação do FNMC por meio do Comitê Gestor. 
Com relação às instituições relacionadas às mudanças climáticas, é importante mencionar que a nova estrutura do MMA dada pelo Decreto $\mathrm{n}^{\circ} 8.975 / 17$ criou a Secretaria de Mudança do Clima e Florestas. Dessa forma, embora não se possa afirmar que a Secretaria tenha sido criada em decorrência dos documentos internacionais relativos às SDCO, o mesmo não se pode consignar em relação aos documentos internacionais sobre as mudanças climáticas. Além da Secretaria, há ainda a Comissão Interministerial para o Desenvolvimento Sustentável CIDES $^{36}$; a Comissão Interministerial de Mudança Global do Clima ${ }^{37}$; o Fórum Brasileiro de Mudanças Climáticas ${ }^{38}$; e o Comitê Interministerial sobre Mudança do Clima (CIM) ${ }^{39}$.

É possível perceber que as primeiras medidas nacionais relativas ao clima e à biodiversidade a) faziam parte de estratégias gerais para o cumprimento da Agenda XXI; b) eram feitas de forma integrada por vários Ministérios, o que possivelmente levava a uma maior articulação, além de possibilitar uma melhor estrutura. A separação das temáticas em diferentes órgãos provavelmente tenha ocorrido em face de um maior conhecimento sobre elas, ou seja, do avançar do conhecimento, bem como pela avocação do MMA em temas de sua competência.

\section{DESCRIÇÃO DOS RESULTADOS COM A APLICAÇÃO DOS CRITÉRIOS DE EFETIVIDADE}

A descrição dos resultados com a aplicação da matriz (item 1) no conjunto normativoinstitucional (item 2) será feita como antes nas duas áreas que compõem o regime do clima: Camada de Ozônio e mudanças climáticas.

\footnotetext{
${ }^{36}$ Criada em 1994, pelo Decreto $n^{\circ} 1.160$, revogado pelo Decreto não numerado de 26/02/97 com a criação da Comissão de Políticas de Desenvolvimento Sustentável, o qual foi revogado pelo Decreto não numerado 28/11/03, o qual também o foi pelo Decreto não numerado em vigor de 03/02/04. No texto do Decreto 1.160/94 é possível perceber que existiam três coordenadorias, cada uma vinculada a um Ministério diferente.

37 Criada em 1999 pelo Decreto não numerado de 07/07/99, alterada pelo Decreto não numerado de $10 / 01 / 06$.

${ }^{38}$ Criado pelo Decreto $n^{\circ} 3.515 / 00$ o qual, no mesmo ano, foi revogado pelo Decreto não numerado de 28/08/00 sendo alterado pelo Decreto não numerado de 14/11/00.

${ }_{39}$ Criado em 2007, pelo Decreto $\mathrm{n}^{\circ}$ 6.263/07. No âmbito do Comitê Interministerial sobre Mudança do Clima, em 2007, foi instituído o Grupo Executivo (GEx) e, no âmbito dele, o Núcleo de Articulação Federativa para o Clima criado em 2013.
} 


\subsection{Camada de Ozônio}

Analisando a Convenção de Viena sobre as substâncias que destroem a camada de Ozônio, foi possível observar que dos oito critérios, seis deles tiveram aplicação positiva (três de natureza material e três de natureza formal) e apenas dois deles (de natureza material) tiveram aplicação parcial.

Com relação aos critérios que tiveram aplicação positiva, é possível afirmar que, materialmente, a Convenção assegura a proteção ambiental na medida em que as Partes devem tomar medidas a fim de proteger o meio ambiente contra efeitos adversos que resultem, ou possam resultar, de atividades humanas que modifiquem ou possam modificar a Camada de Ozônio, conforme art. $2^{\circ}$, $1^{\circ}$. De acordo com o preâmbulo, o reconhecimento de que há um impacto potencialmente prejudicial ao meio ambiente decorrente de modificações na Camada de Ozônio traz um indício de que o comportamento atual não condiz com a proteção ambiental, motivo pelo qual a Convenção conduz à modificação do comportamento humano. A produção de impacto por sua própria existência pode ser vista tanto juridicamente pelo estabelecimento da Conferência ( $\operatorname{art} .6^{\circ}, \S 1^{\circ}$ ) e da possibilidade na elaboração de Protocolos decorrentes dela, como extrajuridicamente pela sinalização enviada à comunidade internacional de que os Estados que participam no referido documento preocupam-se com tal tema. Isso traz reflexos na diplomacia, na economia, nos investimentos econômicos que podem vir a ser feitos, nos investimentos sociais que não serão feitos, etc.

Formalmente, a Convenção entrou em vigor em tempo razoável, já que, elaborada em 1985, passou a vigorar três anos após, em 1988. As formas de garantir a conformidade podem ser identificadas por meio de todas as maneiras de cooperação previstas nos arts. $2^{\circ}$ a $5^{\circ}$, bem como pela revisão constante da Convenção pela Conferência prevista no art. $6^{\circ}$, $\S 4^{\circ}$. Por fim, os meios para promover o cumprimento podem ocorrer via solução de disputas prevista no art. 11.

Já com relação aos critérios materiais que tiveram aplicação parcial, as obrigações consideradas claras podem ser identificadas no art. $4^{\circ}, \$ 1^{\circ}$, referente à obrigação de facilitar e encorajar o intercâmbio de informação científica, técnica, socioeconômica, comercial e jurídica, ainda existindo o anexo II a respeito; no $\$ 2^{\circ}$ do mesmo artigo, no que tange à obrigação de cooperar nas Áreas Jurídica, Científica e Técnica e no art. $5^{\circ}$ referente à obrigação de transmitir informações ao Secretariado. Todavia, consideram-se obrigações não claras aquelas previstas no art. $2^{\circ}, \$ 1^{\circ}$, que menciona a obrigação de "tomar medidas adequadas" a fim de proteger a saúde humana e o meio ambiente contra efeitos adversos que 
resultem, ou possam resultar, de atividades humanas que modifiquem ou possam modificar a Camada de Ozônio, sendo considerada vaga, e no art. $2^{\circ}$, § $2^{\circ}$ (cooperação e adoção de medidas), uma vez que são flexíveis na medida em que as partes devem cumpri-las "de acordo com os meios à sua disposição e de suas possibilidades”. Por fim, as metas consideradas claras estão previstas no art. $2^{\circ} \S 2^{\circ}$, “a”, “b”, “c”, e referem à cooperação e adoção de medidas, e no art. $4^{\circ}, \S 2^{\circ}$ referente à meta de cooperar nas Áreas Jurídica, Científica e Técnica. A meta que não dispõe de método pode ser encontrada no art. $2^{\circ}, \$ 2^{\circ}$, “d”, referente a cooperar com organismos internacionais competentes para implementar efetivamente essa Convenção e protocolos de que sejam Partes. Tal parcialidade é própria das Convenções, já que dispõe de disposições gerais.

Analisando o Protocolo de Montreal foi possível verificar que dos oito critérios, seis deles (quatro de natureza material e três de natureza formal) tiveram aplicação positiva e dois deles (ambos de natureza material) tiveram aplicação parcial.

Com relação aos critérios que tiveram aplicação positiva, é possível afirmar que, materialmente, o Protocolo assegura a proteção ambiental por meio do que dispõem os seus considerandos $n^{\circ} 1$, referente a tomar medidas apropriadas para proteger a saúde humana e 0 meio ambiente, e $n^{\circ} 5$, que visa proteger a camada de Ozônio. Da mesma forma, o Protocolo conduz à modificação do comportamento humano, uma vez que reduzir o consumo das substâncias que destroem a Camada de Ozônio exige uma conduta ativa e leva à conclusão de que o comportamento anterior baseava-se em um consumo maior. O referido documento tem impacto por meio de sua existência juridicamente, na medida em que o compromisso assumido pelas Partes estabelece um controle sobre as SDCO. Além disso, por meio de reunião das partes (art. $11^{\circ}$ ) será possível acompanhar a implementação desse Protocolo. De forma extrajurídica, o documento também produz impacto pela sinalização enviada à comunidade internacional.

Formalmente houve, em tempo razoável, a entrada em vigor do Protocolo, uma vez que ele foi elaborado em 1987, tendo passado a vigorar em 1989, dois anos após a sua elaboração. A avaliação e a revisão das medidas de controle previstas no art. $6^{\circ}$ e o mecanismo financeiro estabelecido na nova redação do art. 10 podem ser consideradas formas de garantir a conformidade. 0 meio para promover o cumprimento pode ser observado no art. $8^{\circ}$, referente à aprovação de procedimentos e mecanismos institucionais para determinados casos de nãocumprimento.

Os critérios que tiveram aplicação parcial são os relacionados às obrigações e às metas. Isso porque existem obrigações claras, como a obrigação das partes de "assegurar" o nível de 
consumo prevista no art. $2^{\circ}$, § $1^{\circ}$ a $4^{\circ}, 2^{\circ} \mathrm{C}, 2^{\circ} \mathrm{D}, 2^{\circ} \mathrm{E}$ e $2^{\circ} \mathrm{F} \S 1^{\circ}$, ou ainda a obrigação de notificar o Secretariado sobre qualquer transferência de produção ou qualquer adição à produção feita, prevista no art. $2^{\circ}$, § $5^{\circ}$, § $5^{\circ}$ bis e $\$ 7^{\circ 40}$. Mas também existem obrigações não claras, como a obrigação de tomar "medidas necessárias" para garantir o nível de consumo, prevista no art. $2^{\circ} \mathrm{F}, \S 2^{\circ}$ a $\S 6^{\circ}$, uma vez que é vaga, ou ainda a obrigação de tomar "medidas necessárias" para garantir o nível de consumo prevista no art. $2^{\circ} \mathrm{G}^{41}$. Além disso, há metas que dispõem de métodos como a de cooperar na promoção de tecnologia e possíveis alternativas, previstas no art. $9^{\circ}$, $\S 1^{\circ}$, ou a meta de cooperar na promoção de uma conscientização pública, prevista no art. $9^{\circ}$, $\S 2^{\circ 42}$, mas existem metas que não dispõem de métodos, como a de "assegurar" o nível de consumo prevista no art. $2^{\circ}$, § $1^{\circ}$ a $4^{\circ}$, $2^{\circ} \mathrm{C}, 2^{\circ} \mathrm{D}, 2^{\circ} \mathrm{E} \mathrm{e} 2^{\circ} \mathrm{F} \S 1^{\circ}$, que não menciona como isso deve acontecer, e a meta dos países em desenvolvimento não excederem nível anual de consumo, prevista no art. $5^{\circ}$, § $3^{\circ}$.

Para uma melhor visualização da aplicação dos critérios de efetividade no plano global, segue o quadro abaixo.

\begin{tabular}{|llll|}
\multirow{3}{*}{ MATERIAL } & CRITERIOS & CONVENÇÃO & PROTOCOLO \\
\cline { 2 - 4 } & Assegurar a proteção ambiental & Positivo & Positivo \\
\cline { 2 - 4 } & Conduzir a modificação no comportamento humano & Positivo & Positivo \\
\cline { 2 - 4 } & Tiver impacto só por meio de sua própria existência & Positivo & Positivo \\
\cline { 2 - 4 } & Possuir clareza no conteúdo das obrigações & Parcial & Parcial \\
\cline { 2 - 4 } & Dispor de metas e métodos & Parcial & Parcial \\
\hline \multirow{2}{*}{ FORMAL } & Tiver entrado em vigor em tempo razoável & Positivo & Positivo \\
\cline { 2 - 4 } & Contiver formas de garantir a conformidade & Positivo & Positivo \\
\cline { 2 - 4 } & Contiver meios para promover o cumprimento & Positivo & Positivo \\
\hline
\end{tabular}

Em relação ao grupo das SDCO, foi possível encontrar, no âmbito interno, oito normas internalizantes, nenhuma norma específica e nove normas exequentes. Além disso, duas Instituições foram citadas como tendo sido criadas em decorrências dos documentos internacionais relacionados a esse tema.

Dos quatro critérios aplicados às normas internalizantes, três tiveram aplicação positiva. Eles associam-se à correspondência com os objetivos do tratado ambiental, à condução

\footnotetext{
${ }^{40}$ Além destas, são consideradas obrigações claras as obrigações previstas no art. $4^{\circ}, \S 1^{\circ}$ a $\S 1^{\circ}$ sex e $\S 2^{\circ}$ a $\S 2^{\circ}$ sex; no art. $4^{\circ}, \$ 3^{\circ}$ a $\S 3^{\circ}$ ter; no art. $4^{\circ} \mathrm{A}$; no art. $4^{\circ} \mathrm{B}$; no $\operatorname{art.} 4^{\circ}, \S 6^{\circ}$; no art. $5^{\circ}$; no art. $6^{\circ}$; no art. $7^{\circ}$; no art. $9^{\circ}, \S 1^{\circ}$; no art. $9^{\circ}, \$ 2^{\circ}$; no art. $9^{\circ}, \S 3^{\circ} \mathrm{e}$ no art. $11^{\circ}$.

${ }^{41}$ Além destas, são consideradas obrigações não claras as obrigações previstas no art. $2^{\circ} \mathrm{F}$ e no art. $10^{\circ} \mathrm{A}$.

42 Além destas há ainda a meta prevista no art. $10^{\circ}$, § $1^{\circ}$ que, embora não disponha de método, remete ao art. $4^{\circ}$ da Convenção que dispõe.
} 
ISSN 1981-3694

(DOI): $10.5902 / 1981369430027$

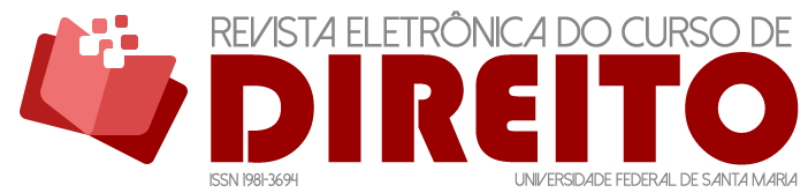

A INFLUÊNCIA DOS TRATADOS AMBIENTAIS MULTILATERAIS RELATIVOS AO CLIMA NA EFETIVIDADE DO DIREITO AMBIENTAL NO BRASIL

LAUREN LAUTENSCHLAGER MARCELO DIAS VARELLA

à modificação no comportamento humano e a terem impacto só por meio de sua própria existência.

Apenas um deles teve aplicação parcial. Esse critério refere-se à entrada em vigor em tempo razoável, já que aplicado de forma diversa de acordo com o tipo da norma em questão.

Com relação às normas exequentes, o único critério que se mostrou positivo em suas 10 normas foi o critério de correspondência com o objetivo do tratado ambiental. A correspondência pode ser observada na Portaria $n^{\circ}$ 534/88 que se refere à proibição de fabricação e comercialização de alguns produtos relacionando apenas a uma das substâncias (CFC) - ANEXO A. Isso ocorre da mesma forma na Portaria ${ }^{\circ}$ 647/89, já que ela busca especificar as substâncias da portaria anterior; na Portaria $n^{\circ}$ 29/95, uma vez que exige o cadastramento ou recadastramento e o envio de dados das empresas que tenham contato com as SDCO; na Resolução $n^{\circ}$ 267/00, na medida em que amplia a proibição das atividades/produtos, bem como as substâncias antes previstas na Portaria 534 (ANEXO A E B); na Resolução n 340/03, uma vez que proíbe a liberação de substâncias na atmosfera, exigindo o recolhimento. Na Instrução Normativa $n^{\circ} 01 / 02$, a correspondência pode ser vista, na medida em que essa norma faz referência à eliminação do brometo de metila; na Instrução Normativa $n^{\circ} 37 / 04$, quando amplia o que se entende por usuários de SDCO; na Instrução Normativa n 207/08, quando limita a importação de HCFC; na Instrução Normativa $n^{\circ} 14 / 12$, quando dispõe sobre importação de HCFC; e na Portaria ${ }^{\circ}$ 212/12, quando institui o Programa Brasileiro de Eliminação dos HCFCs $\mathrm{PBH}$.

Dessa forma, é possível perceber correspondência das normas exequentes aos documentos internacionais, embora aquelas sejam elaboradas de forma separada em relação ao tipo de atividade a ser desenvolvida, bem como a substância a ser regulada.

Um critério não pode ser aplicado, qual seja, o critério sobre a completude das normas, uma vez que todas essas normas figuram como normas finais.

Finalmente, um dos critérios foi observado de forma negativa, qual seja, o critério sobre dispor de metas e métodos, em face da inexistência de metas específicas.

Os demais critérios mostraram-se parciais. O critério de entrar em vigor em tempo razoável teve aplicação negativa na Portaria $n^{\circ}$ 29/95, na Resolução $n^{\circ} 267 / 00$, nas Instruções Normativas $n^{\circ}$ 01/02, 37/04, 12/12 e na Portaria $n^{\circ} 212 / 12$. O critério de possuir clareza no conteúdo das obrigações não pode ser aplicado em quatro normas, Portarias n 534/88, 647/89, 
212/12 e Resolução $n^{\circ} 340 / 03$ em face da tipologia dessas ${ }^{43}$. Todavia, teve aplicação positiva nas demais (Resolução $n^{\circ}$ 267/00, Instruções Normativas $n^{\circ}$ 01/02, 37/04, 207/08 e 14/12). Na Portaria $n^{\circ} 29 / 95$, as obrigações de cadastro e envio de dados nos prazos estipulados previstas nos art. $1^{\circ}$ a $3^{\circ}$, bem como a obrigação de recadastramento prevista no art. $5^{\circ}$ são claras. $\mathrm{Na}$ Resolução $n^{\circ} 267 / 00$, além de disposições cogentes previstas nos art. $1^{\circ}$ a $3^{\circ}, 5^{\circ}, 6^{\circ}$ e $8^{\circ}$, as obrigações existentes são claras, como a obrigação de algumas empresas efetuarem um cadastro (art. $9^{\circ}$ ); a obrigação das empresas cadastradas fornecerem inventários (art. 10) e a obrigação das empresas vendedoras enviarem uma relação das empresas compradoras (art. 11). Na Instrução Normativa $n^{\circ}$ 01/02, há obrigações claras existentes para as empresas, as quais devem ter técnicos e operadores habilitados (art. $6^{\circ}$ ) e emitir relatórios (art. $7^{\circ}$ ), bem como para a Secretaria, a qual deve enviar relatórios (art. $9^{\circ}$ ). Com relação à Instrução Normativa $n^{\circ} 37 / 04$, as obrigações são claras, como o dever de renovar o registro a todas as empresas já registradas e que já apresentaram o Inventário Anual com os dados quantitativos e qualitativos relativos às substâncias controladas e alternativas utilizadas e/ou comercializadas, correspondente ao exercício de 2003 (art. 3º parágrafo único). A Instrução Normativa n 207/08 possui uma obrigação clara e refere-se à obrigação de registrar licenças (art. $7^{\circ}$ ). Por fim, na Instrução Normativa $n^{\circ} 14 / 12$, as obrigações existentes são claras e referem-se ao registro da licença de importação $\left(\operatorname{art} .8^{\circ}\right)$, a qual já existia na IN 207, e a de recolhimento e destinação adequada dos gases (art. 12).

As normas exequentes que tiveram aplicação positiva do critério de clareza nas obrigações referem às obrigações também consideradas claras no Protocolo de Montreal, especificamente a obrigação de assegurar o nível de consumo das SDCO, a de estabelecer e implementar um sistema de licenciamento para as importações e exportações de SDCO e a de informar dados estatísticos ao Secretariado.

O critério sobre conduzirem a modificação no comportamento humano teve aplicação negativa apenas em uma das normas exequentes, a Portaria $n^{\circ}$ 647/89. De forma positiva, 0 critério sobre a condução na modificação do comportamento humano aparece na Portaria $n^{\circ}$ 344/88, na medida em que a fabricação e a comercialização que antes eram permitidas tornaram-se proibidas; na Portaria $n^{\circ} 29 / 95$, pois exige o cadastramento, o recadastramento e o envio de dados; na Resolução $n^{\circ} 267 / 00$, uma vez que proíbe atividades e impõe obrigações que

\footnotetext{
${ }^{43}$ A não aplicação do critério na Portaria $n^{\circ} 534 / 88$ e na Resolução $n^{\circ} 340 / 03$ ocorreu em face delas possuírem apenas disposições cogentes. Na Portaria $n^{\circ} 647 / 89$, porque ela somente especifica as substâncias da portaria anterior (Portaria $n^{\circ} 534 / 88$ ). No que concerne à Portaria $n^{\circ} 212 / 12$, porque ela visa instituir o Programa Brasileiro de Eliminação dos HCFCs - PBH.
} 
antes não existiam; na Resolução $n^{\circ} 340 / 03$, já que ela exige recipientes adequados para guardar as substâncias; na Instrução Normativa $n^{\circ}$ 01/02, na medida em que proíbe o uso de brometo de metila; na Instrução Normativa no 37/04, exigindo um novo cadastramento; na Instrução Normativa n 207/08, fixando um limite máximo de importação de HCFC; na Instrução Normativa $n^{\circ} 14 / 12$, no que tange à recolha e à destinação dos gases; e na Portaria $n^{\circ} 212 / 12$, uma vez que o programa visa eliminar o consumo de HCFCs.

Da mesma forma, o critério sobre ter impacto só por meio de sua própria existência teve aplicação negativa apenas em uma das normas exequentes, isto é, na Portaria $n^{\circ}$ 647/89.

0 critério sobre formas de garantir a conformidade não pode ser aplicado em quatro normas em face das suas tipologias (Portarias $n^{\circ}$ s 534/88, 647/88, 212/12 e Resolução $n^{\circ}$ $340 / 03$ ). Foi encontrado em forma positiva em apenas uma das normas, na Resolução $n^{\circ} 267 / 00$, por meio de um reforço na fiscalização, conforme previsão dos art. 12 e 13. Ademais, foi encontrado de forma negativa nas quatro Instruções Normativas (01/02, 37/04, 207/08 e 14/12). Da mesma forma, o critério sobre meios para promover o cumprimento também não pode ser aplicado em quatro normas em face das suas tipologias (Portarias n's 534/88, 647/88, 212/12 e Resolução $\left.n^{\circ} 340 / 03\right)$. Todavia, foi encontrado em forma positiva em quatro normas, em que há menção que o não cumprimento da norma leva à aplicação de sanções (na Portaria $n^{\circ}$ 29/95 em seu art. $6^{\circ}$, na Resolução ${ }^{\circ} 267 / 00$ em seu art. 15º; na Instrução Normativa $n^{\circ} 37 / 04$ em seu art. $7^{\circ}$; Instrução Normativa $n^{\circ} 207 / 08$ em seu art. $9^{\circ}$ e na Instrução Normativa $n^{\circ} 14 / 12$ em seu art. $\left.13^{\circ}\right)$.

No que tange às duas Instituições das SDCO, o critério de completude não pode ser aplicado, uma vez que tais Instituições são órgãos finais.

Os demais critérios foram observados de forma positiva em ambas as Instituições. 0 critério de criação em tempo razoável foi positivo no Comitê Executivo Interministerial PROZON, uma vez que a data de entrada em vigor da Convenção e do Protocolo ocorreu em 1990 e tal Comitê, embora tenha sido criado em 1995, deu continuidade ao extinto Grupo criado ainda no ano de 1991. Isso ocorreu da mesma forma no Grupo de trabalho HCFCs. 0 critério de correspondência com o objetivo das normas criadas foi positivo no Comitê Executivo Interministerial - PROZON, na medida em que ele e o extinto Grupo relacionavam-se com o Programa Nacional de Implementação do Protocolo de Montreal. Isso ocorreu da mesma forma no Grupo de trabalho HCFCs, já que ele tem como objetivo auxiliar o governo brasileiro na elaboração e na implementação do $\mathrm{PBH}$. Por último, o critério sobre terem vitalidade 
ISSN 1981-3694

(DOI): $10.5902 / 1981369430027$

\section{U DIREITO}

A INFLUÊNCIA DOS TRATADOS AMBIENTAIS MULTILATERAIS RELATIVOS AO CLIMA NA EFETIVIDADE DO DIREITO AMBIENTAL NO BRASIL

LAUREN LAUTENSCHLAGER MARCELO DIAS VARELLA

institucional foi positivo, já que ambas as Instituições utilizam o orçamento e a estrutura dos ministérios que as compõem.

Para uma melhor visualização da aplicação dos critérios de efetividade no plano interno, segue quadro:

\begin{tabular}{|c|c|c|c|}
\hline & CRITERIOS & INTERNALIZANTES & EXEQUENTES \\
\hline \multirow[t]{9}{*}{ NORMATIVO } & Entrada em vigor em tempo razoável & Parcial & Parcial \\
\hline & $\begin{array}{l}\text { Correspondência com objetivo dos } \\
\text { tratados }\end{array}$ & Positivo & Positivo \\
\hline & Clareza no conteúdo das obrigações & $\begin{array}{l}\text { Não existente nesse conjunto } \\
\text { de normas }\end{array}$ & Parcial \\
\hline & Dispor de metas e métodos & $\begin{array}{l}\text { Não existente nesse conjunto } \\
\text { de normas }\end{array}$ & Negativo \\
\hline & Completude & $\begin{array}{l}\text { Não existente nesse conjunto } \\
\text { de normas }\end{array}$ & Não aplicado \\
\hline & $\begin{array}{l}\text { Conduzir à modificação no } \\
\text { comportamento humano }\end{array}$ & Positivo & Parcial \\
\hline & $\begin{array}{l}\text { Tiver impacto só por meio de sua } \\
\text { própria existência }\end{array}$ & Positivo & Parcial \\
\hline & $\begin{array}{l}\text { Contiverem formas de garantir a } \\
\text { conformidade }\end{array}$ & $\begin{array}{l}\text { Não existente nesse conjunto } \\
\text { de normas }\end{array}$ & Parcial \\
\hline & $\begin{array}{l}\text { Contiverem meios para promover o } \\
\text { cumprimento }\end{array}$ & $\begin{array}{l}\text { Não existente nesse conjunto } \\
\text { de normas }\end{array}$ & Parcial \\
\hline \multirow[t]{4}{*}{ INSTITUCIONAL } & Criados em tempo razoável & \multicolumn{2}{|l|}{ Positivo } \\
\hline & $\begin{array}{l}\text { Correspondem com o objetivo das } \\
\text { normas criadas }\end{array}$ & \multicolumn{2}{|l|}{ Positivo } \\
\hline & $\begin{array}{l}\text { Forem completos, com todos os } \\
\text { órgãos necessários }\end{array}$ & \multicolumn{2}{|l|}{ Não aplicado } \\
\hline & Tiverem vitalidade institucional & \multicolumn{2}{|l|}{ Positivo } \\
\hline
\end{tabular}

\subsection{Mudanças climáticas}

Analisando a Convenção das Nações Unidas sobre mudanças climáticas, com melhor estrutura que a Convenção anterior, foi possível observar que dos oito critérios, seis deles tiveram aplicação positiva (três de natureza material e três de natureza formal) e apenas dois deles (de natureza material) tiveram aplicação parcial.

Com relação aos que tiveram aplicação positiva, é possível assinalar que, materialmente, a Convenção assegura a proteção ambiental, uma vez que o seu art. $2^{\circ}$ menciona que o objetivo é o de alcançar a estabilização das concentrações de GEE na atmosfera, num nível que impeça uma interferência antrópica perigosa ao sistema climático. Assim, frear a emissão a ponto de estabilizá-la leva a uma melhora na qualidade ambiental. 0 referido 
documento conduz a modificação do comportamento humano, pois, no preâmbulo, há o reconhecimento que as atividades humanas estão aumentando as concentrações atmosféricas de GEE, fazendo com que ocorra um aquecimento da superfície e da atmosfera da Terra, o que pode afetar negativamente os ecossistemas naturais e a humanidade. 0 impacto produzido ocorre na área jurídica pelo estabelecimento da Conferência (art. $7^{\circ}$ ) e pela possibilidade de Protocolos a esta, mas também se dá na área extrajurídica pela sinalização enviada a comunidade internacional.

Formalmente, a Convenção entrou em vigor em tempo razoável, uma vez que foi elaborada em 1992 e passou a vigorar dois anos depois. Além disso, ela contém formas de garantir a conformidade, as quais podem ser observadas no art. $4^{\circ}, \S 2^{\circ}$, “b”, referente à obrigação de informar as políticas adotadas; no art. 10, via órgão subsidiário de implementação, e no art. 11, por meio do mecanismo para provisão de recursos financeiros. Por fim, o referido documento contém meios de promover o cumprimento mediante a solução de controvérsias, estabelecida no art. 14.

Já com relação aos critérios materiais que tiveram aplicação parcial, a obrigação considerada clara pode ser identificada no art. $4^{\circ}, \S 3^{\circ}$, a qual refere a obrigação das partes desenvolvidas em prover recursos financeiros. As obrigações não claras encontram-se previstas no art. $4^{\circ}, \S 1^{\circ}$, sendo consideradas flexíveis na medida em que as partes devem "levar em conta suas responsabilidades comuns, mas diferenciadas e suas prioridades de desenvolvimento, objetivos e circunstâncias específicos, nacionais e regionais". Além da flexibilidade, podem ser consideradas normas vagas ainda as alíneas "e" (planos adequados) e "f" (métodos adequados) ${ }^{44}$. Por fim, as metas consideradas claras associam-se à meta de promover e cooperar para o desenvolvimento, a aplicação e a difusão de práticas e processos que controlem, reduzam ou previnam as emissões antrópicas, previstas no art. $4^{\circ}, \S 1^{\circ}$, “c", que menciona a via de transferência de tecnologia, ou ainda levar em conta, na medida do possível, os fatores relacionados com a mudança do clima em suas políticas e medidas, bem como empregar métodos adequados com vistas a minimizar os efeitos negativos, previsto no art. $4^{\circ}$, § $1^{\circ}$ “f”, que menciona quais serão esses métodos ${ }^{45}$. Finalmente, as metas consideradas sem métodos referem-se à meta de elaborar, atualizar periodicamente, publicar e por à disposição inventários nacionais conforme previsão no art. $4^{\circ}, \$ 1^{\circ}$, “a”, que terá a metodologia definida na Conferência das partes; ou ainda à meta de promover a gestão sustentável, bem como promover e cooperar

\footnotetext{
${ }^{44}$ Consideram-se obrigações vagas também, as previstas no art. $4^{\circ}$, § $2^{\circ}$ " e a prevista no art. $4^{\circ}$, § $5^{\circ}$.

${ }^{45}$ Além destas, podem ser consideradas metas claras as metas previstas no art. $4^{\circ}, \$ 1^{\circ}$, "g" que traz o seu método no art. $5^{\circ}$ e a prevista no art. $4^{\circ}, \$ 1^{\circ}$ “i”, que traz o seu método no art. $6^{\circ}$.
} 
na conservação e fortalecimento, conforme o caso, de sumidores e reservatórios de todos os gases de efeito estufa, que está prevista no art. $4^{\circ}$, § $1^{\circ}$, “d”. .

Analisando o Protocolo de Quioto, foi possível observar que dos oito critérios, cinco deles tiveram aplicação positiva (três de natureza material e dois de natureza formal), dois deles (de natureza material) tiveram aplicação parcial e um deles (de natureza formal) teve aplicação negativa.

Com relação aos critérios que tiveram aplicação positiva, é possível afirmar que, materialmente, o Protocolo assegura a proteção ambiental, uma vez que menciona a necessidade de redução de emissões totais dos gases no período de compromisso de 2008 a 2012 $\left(\right.$ art. $\left.3^{\circ}\right)$. A própria adesão ao Protocolo conduz a uma postura diferente da que vinha sendo adotada, já que exige uma limitação na emissão de GEE. Dessa forma, o documento conduz à modificação do comportamento humano. Além disso, ele tem impactos só por meio de sua existência. Tais impactos podem ser verificados no campo jurídico, já que foi estabelecido o mecanismo de desenvolvimento limpo, e também podem ser observados no campo extrajurídico, pois sempre existe a emissão de um sinal à comunidade internacional na adoção do documento por cada Estado-Parte.

Formalmente, o Protocolo dispõe de formas de garantir a conformidade no art. 15, com o Órgão Subsidiário de Implementação, e no art. 18, via procedimento e mecanismos para determinar e tratar de casos de não cumprimento. Como o documento assinala a mesma solução de controvérsias da Convenção conforme o art. 19, é correto afirmar que ele contém meios para promover o cumprimento.

Os critérios materiais que tiveram aplicação parcial referem-se às obrigações e metas. Isso porque são consideradas obrigações claras a obrigação de cooperar, prevista no art. $2^{\circ}, \S^{\circ}$, "b", ou ainda de limitar ou reduzir as emissões de GEE originárias de combustíveis do transporte aéreo e marítimo internacional prevista no art. $2^{\circ}$, $\S 2^{\circ 47}$. Mas também existem obrigações não claras, como a obrigação de implementar e/ou aprimorar políticas e medidas "de acordo com suas circunstâncias nacionais" prevista no art. $2^{\circ}, \$ 1^{\circ}$, “a”, pois é flexível, ou ainda a obrigação de "quando apropriado e na medida do possível", programas nacionais "adequados", eficazes em relação aos custos, para melhorar a qualidade dos fatores de emissão,

\footnotetext{
${ }^{46}$ São consideradas metas sem métodos, as metas previstas no art. $4^{\circ}$, § $1^{\circ}$ "e" e no art. $4^{\circ}$, § $1^{\circ}$ "h" (segunda parte).

47 São ainda consideradas obrigações claras as obrigações contidas no $\operatorname{art.~}^{\circ}$, §3; no art. $3^{\circ}$, § $1^{\circ}$; no art. $3^{\circ}$, § $4^{\circ}$; no $\operatorname{art.} 5^{\circ}, \S 1^{\circ}$; no $\operatorname{art} .7^{\circ}$, § $1^{\circ}$; no art. $7^{\circ}$, § $2^{\circ}$; no art. $10^{\circ}$, "b"; no art. $10^{\circ}$, "d"; no art. $10^{\circ}$ "e" e no $\operatorname{art.} 11^{\circ}, \S 2^{\circ}$.
} 
dados de atividade e/ou modelos locais que reflitam as condições socioeconômicas de cada Parte para a preparação e a atualização periódica de inventário prevista no art. 10, “a”, que é, ao mesmo tempo, vaga e flexível $^{48}$. Da mesma forma, são consideradas metas claras as encontradas no art. $2^{\circ}, \S 1^{\circ}$, “b”, referente à cooperação, ou ainda no art. $3^{\circ}, \S 1^{\circ} \mathrm{c} / \mathrm{c}$ art. $6^{\circ}$ sobre assegurar o nível de emissões antrópicas agregadas acordado ${ }^{49}$. Contudo, algumas metas não podem ser consideradas claras, pois não dispõem de métodos, como a encontrada no art. $5^{\circ}$, $\S 1^{\circ}$, referente a estabelecer um sistema nacional para a estimativa das emissões antrópicas por fontes e das remoções antrópicas por sumidouros de todos os GEE, e no art. 10, “c”, referente à cooperação na promoção de modalidades efetivas para o desenvolvimento, a aplicação e a difusão e tomar todas as medidas possíveis para promover, facilitar e financiar a transferência ou o acesso a tecnologias.

O critério formal que teve aplicação negativa refere-se à entrada em vigor em tempo razoável, uma vez que o Protocolo foi feito em 1997 e entrou em vigor apenas em 2005.

Analisando o Acordo de Paris, foi possível observar que dos oito critérios, cinco deles tiveram aplicação positiva (quatro de natureza material e dois de natureza formal), dois deles (de natureza material) tiveram aplicação parcial e um deles (de natureza formal) não pode ser aplicado.

Com relação aos critérios que tiveram aplicação positiva, é possível afirmar que, materialmente, o Acordo assegura a proteção ambiental, uma vez que visa reforçar a resposta global à ameaça das alterações climáticas. Ele induz à modificação do comportamento humano na medida em que segura o aumento da temperatura média global. Tem impactos só por meio de sua existência, tanto juridicamente, via mecanismos estabelecidos e novas metas a serem cumpridas, como extrajuridicamente, pela sinalização repassada à comunidade internacional.

Formalmente, o Acordo contém formas de garantir a conformidade, já que foi instituído um mecanismo para contribuir para a mitigação das emissões de GEE e apoiar o desenvolvimento sustentável, conforme art. $6^{\circ}$, $4^{\circ}$; foi definido um "quadro para abordagens não-mercado", de acordo com o art. $6^{\circ}, \S 8^{\circ 50}$. Além disso, o documento ora em análise possui os mesmos meios de promover o cumprimento que se acham previstos em sua Convenção.

\footnotetext{
48 São ainda consideradas obrigações não claras as previstas no art. $10^{\circ}$, "c", que é vaga.

${ }^{49}$ Além destas, as metas claras podem ser verificadas no art. $10^{\circ}$, "d" c/c art. $5^{\circ}$ da Convenção e no art. $10^{\circ}$, "e" c/c art $6^{\circ}$ da Convenção.

${ }^{50}$ Foi ainda instituído um Mecanismo de Warsaw International por perdas e danos associados a mudanças climáticas, previsto no art. $8^{\circ}$; foi definido um quadro de transparência previsto no art. $13^{\circ}$; um balanço periódico da aplicação desse documento deve ser realizado pela Conferência, consoante art. $14^{\circ}$ e foi
} 
Os critérios materiais que tiveram aplicação parcial referem-se às obrigações e às metas. Isso porque existem obrigações claras como a prevista no art. $4^{\circ}, \S 1^{\circ}$, concernente à obrigação de atingir o pico global das emissões de GEE, ou a que consta no art. $4^{\circ}$, § $2^{\circ}$, sobre as obrigações de preparar, comunicar e manter sucessivas contribuições determinadas em nível nacional, as quais se pretende alcançar ${ }^{51}$. Todavia, as duas obrigações que constam no art. $5^{\circ}$, referentes a tomar medidas para conservar e reforçar sumidouros e reservatórios e tomar medidas para redução do desmatamento e degradação das florestas, não podem ser consideradas obrigações claras, uma vez que não mencionam quais as medidas que devem ser tomadas. Da mesma forma, as metas que possuem métodos referem-se à meta de reforçar a sua cooperação em matéria de reforço da ação de adaptação prevista no art. $7^{\circ}$, § $7^{\circ}$, ou a de apresentar e atualizar periodicamente em uma comunicação de adaptação prevista no art. $7^{\circ}$, § $10^{\circ 52}$, mas também foram encontradas metas que não dispõem de métodos como a meta de atingir pico global de emissões de GEE prevista no art. $4^{\circ}$, $\S 1^{\circ}$, e a meta de cooperar para melhorar a educação à mudança climática, a formação, a sensibilização pública, a participação do público e o acesso do público à informação, prevista no art. 12.

O critério formal sobre a entrada em vigor em tempo razoável não pode ser aplicado, uma vez que o Acordo se encontra em fase de assinaturas.

Para uma melhor visualização da aplicação dos critérios de efetividade no plano global, especificamente aos documentos internacionais relacionados às mudanças climáticas, segue quadro:

\begin{tabular}{|c|c|c|c|c|}
\hline & CRITERIOS & CONVENÇĀO & PROTOCOLO & ACORDO \\
\hline \multirow[t]{5}{*}{ MATERIAL } & Assegurar a protecão ambiental & Positivo & Positivo & Positivo \\
\hline & $\begin{array}{l}\text { Conduzir a modificação no comportamento } \\
\text { humano }\end{array}$ & Positivo & Positivo & Positivo \\
\hline & $\begin{array}{l}\text { Tiver impacto só por meio de sua própria } \\
\text { existência }\end{array}$ & Positivo & Positivo & Positivo \\
\hline & Possuir clareza no conteúdo das obrigações & Parcial & Parcial & Parcial \\
\hline & Dispor de metas e métodos & Parcial & Parcial & Parcial \\
\hline \multirow[t]{3}{*}{ FORMAL } & Tiver entrado em vigor em tempo razoável & Positivo & Negativo & $\begin{array}{l}\text { Não } \\
\text { aplicado }\end{array}$ \\
\hline & Contiver formas de garantir a conformidade & Positivo & Positivo & Positivo \\
\hline & Contiver meios para promover o cumprimento & Positivo & Positivo & Positivo \\
\hline
\end{tabular}

instituído ainda mecanismo para facilitar a implementação e promover o cumprimento das disposições do presente Acordo (comitê), segundo previsão no art. $15^{\circ}$.

${ }^{51}$ Além destas, são consideradas obrigações claras as contidas no art. $7^{\circ}$, § $7^{\circ}$; no art. $7^{\circ}$, § $9^{\circ} ;$ no $\operatorname{art.~} 7^{\circ}$, § $10^{\circ}$; no art. $9^{\circ}$; no art. $10^{\circ}$, § $2^{\circ}$; no art. $11^{\circ}$, § $3^{\circ}$; no art. $12^{\circ}$; no art. $13^{\circ}$, § $7^{\circ}$ a $10^{\circ}$.

${ }^{52}$ Além destas, as metas que dispõem de métodos se referem a meta prevista no art. $10^{\circ}$, $\S 2^{\circ}$ e no art. $11^{\circ}, \S 3^{\circ}$. 
No âmbito interno, quatro normas internalizantes, duas normas específicas e três normas exequentes. Além disso, cinco Instituições foram citadas como tendo sido criadas em decorrência dos documentos internacionais relacionados ao tema.

Três critérios das normas internalizantes tiveram aplicação positiva. Eles referem-se à correspondência com os objetivos do tratado ambiental, à condução à modificação no comportamento humano e a terem impacto só por meio de sua própria existência. Apenas um deles teve aplicação parcial, qual seja, o de terem entrado em vigor em tempo razoável, que foi observado de forma negativa no Decreto Legislativo $n^{\circ} 144 / 02$, quando relacionado com a data de elaboração do Protocolo de Quioto em 1997.

Dois critérios das normas específicas tiveram aplicação positiva. Eles vinculam-se à correspondência com os objetivos do tratado ambiental e têm impacto só por meio de sua própria existência. A correspondência da Lei n $12.144 / 09$ existe porque ela cria um Fundo para assegurar recursos a projetos e financiamento que visem à mitigação e à adaptação à mudança do clima e aos seus efeitos. Ela ocorre da mesma forma na Lei $n^{\circ} 12.187 / 09$, que, embora tenha sido parcialmente vetada, institui princípios (art. $3^{\circ}$ ), objetivos (art. $\left.4^{\circ}\right)$, diretrizes $\left(\operatorname{art.} 5^{\circ}\right)$ e instrumentos (art. $6^{\circ}$ e $7^{\circ}$ ) para atingir o compromisso voluntário (art. 12).

Não foi possível aplicar o critério de clareza no conteúdo das obrigações em face da inexistência delas nesse grupo de normas.

O critério sobre a entrada em vigor em tempo razoável teve aplicação negativa nas duas leis específicas, já que ambas são de 2009 e a Convenção sobre Mudanças Climáticas é de 1992.

Os demais critérios tiveram aplicação parcial. O critério sobre metas e métodos não pode ser aplicado na Lei $n^{\circ} 12.144 / 09$, o que não ocorreu na Lei $n^{\circ} 12.187 / 09$, pois nela a meta do compromisso voluntário (art. 12), embora possa ser atingida, por meio dos instrumentos previstos na Lei (art. $6^{\circ}$ ), exige um detalhamento das ações, o que será feito via Decreto (art. 12, parágrafo único). 0 critério sobre completude foi verificado de forma positiva na Lei $n^{\circ}$ 12.144/09, em face da existência do Decreto Regulamentador, e de forma negativa na Lei $n^{\circ}$ 12.187/09. O critério relacionado à condução na modificação do comportamento humano não pode ser aplicado na Lei $n^{\circ} 12.144 / 09$, tendo sido observado de forma positiva na Lei $n^{\circ} 12.187$, na medida em que as ações a serem feitas devem reduzir a emissão de GEE. 0 critério sobre formas de garantir a conformidade não pode ser aplicado na Lei $n^{\circ} 12.144 / 09$, tendo sido observado de forma positiva na Lei $\mathrm{n}^{\circ} 12.187$, por meio dos instrumentos previstos no art. $6^{\circ}$, das linhas de créditos previstas no art. $8^{\circ}$ e da negociação de títulos mobiliários que se acha prevista 
no art. $9^{\circ} .0$ critério sobre meios para promover o cumprimento não pode ser aplicado na Lei 12.144/09, mas foi observado de forma negativa na Lei $\mathrm{n}^{\circ} 12.187$.

Dois critérios das normas exequentes tiveram aplicação positiva. Um deles refere-se à correspondência com os objetivos do tratado ambiental. O Decreto $n^{\circ} 7.343 / 10$ apresenta correspondência, na medida em que regulamenta o Fundo que assegura recursos para mitigação e à adaptação à mudança do clima e aos seus efeitos. O Decreto $\mathrm{n}^{\circ} 7.390 / 10$, na medida em que regulamenta alguns artigos da Lei sobre a PNMC. A Instrução Normativa $n^{\circ} 12 / 10$, uma vez que exige medidas de mitigação e/ou compensação. 0 outro critério que teve aplicação positiva refere-se ao critério sobre os impactos.

O critério sobre a completude não pode ser aplicado nesse grupo de normas, porque todas elas são normas finais.

Os demais critérios foram observados de forma parcial. 0 critério sobre a entrada em vigor em tempo razoável ocorreu de forma positiva no Decreto $\mathrm{n}^{\circ} 7.343 / 10$, relacionado com a Lei $n^{\circ} 12.144 / 09$, e no Decreto $n^{\circ} 7.390 / 10$, relacionado com a Lei $n^{\circ} 12.187 / 09$. Porém, foi observado de forma negativa na Instrução Normativa $n^{\circ} 12 / 10$. O critério sobre clareza no conteúdo das obrigações não pode ser aplicado nem no Decreto $n^{\circ} 7.343 / 10$ e nem na Instrução Normativa $n^{\circ} 12 / 10$. Por outro lado, foi observado de forma negativa no Decreto $n^{\circ} 7.390 / 10$, que traz a obrigação de elaboração dos planos plurianuais e Leis Orçamentárias Anuais e menciona que o Poder Executivo Federal deverá formular proposta de programas e ações que contemplem o disposto no Decreto (art. $9^{\circ}$ ). A referida obrigação não pode ser considerada clara, uma vez que não menciona quais programas e ações que devem ser feitas, todavia vai ao encontro das obrigações consideradas não claras nos documentos internacionais referentes às mudanças climáticas, como, por exemplo, a obrigação vaga prevista no art. $4^{\circ}$, § $2^{\circ}$, da CMC, concernente à obrigação de "adotar políticas nacionais e medidas correspondentes para mitigar a mudança do clima”; à obrigação de implementar e/ou aprimorar políticas e medidas "de acordo com suas circunstâncias nacionais" prevista no art. $2^{\circ}, \$ 1^{\circ}$, “a”, do Protocolo de Quioto. O critério sobre metas e métodos foi observado de forma negativa no Decreto $\mathrm{n}^{\circ}$ $7.434 / 10$, mas pode ser observado de forma positiva no Decreto $n^{\circ} 7.390 / 10$, pelo disposto no art. $6^{\circ}$. Tal critério não pode ser observado na Instrução Normativa $n^{\circ} 12 / 10$. A condução na modificação do comportamento humano não pode ser aplicada no Decreto $n^{\circ} 7.343 / 10$. No Decreto $n^{\circ} 7.390 / 10$, contudo, foi observada de forma positiva, na medida em que faz o detalhamento das ações para cumprir com o compromisso estabelecido. Da mesma forma, isso ocorreu com a Instrução Normativa $n^{\circ} 12 / 10$. Foi possível encontrar formas de garantir a 
conformidade no Decreto $\mathrm{n}^{\circ} 7.390 / 10$, por meio da possibilidade de revisão e ajuste das ações $\left(\operatorname{art} .6^{\circ}, \S 3^{\circ}\right)$, da adoção de metodologia para aferir o cumprimento (art. 10) e da possibilidade de revisar o Decreto (art.11, parágrafo único). Porém, esse critério não pode ser aplicado no Decreto $n^{\circ} 7.343 / 10$, nem na Instrução Normativa $n^{\circ} 12 / 10$. Por fim, o critério sobre os meios para promover o cumprimento foi observado de forma negativa no Decreto $n^{\circ} 7.390 / 10$ e não foi aplicado nem no Decreto $n^{\circ} 7.343 / 10$, nem mesmo na Instrução Normativa $n^{\circ}$ 12/10.

Com relação às Instituições criadas em decorrência dos documentos internacionais firmados sobre as mudanças climáticas, dois critérios tiveram aplicação positiva, o referente à correspondência com o objetivo das normas criadas e o que diz respeito à completude.

Os critérios restantes tiveram aplicação parcial. O critério sobre a criação em vigor em tempo razoável teve aplicação positiva apenas na Comissão Interministerial de Desenvolvimento Sustentável, criada em 1994, portanto dois anos após a Convenção. Nas demais Instituições, esse critério teve aplicação negativa.

Finalmente, o critério sobre a vitalidade institucional foi observado de forma negativa na Secretaria de Mudança do Clima e Florestas e na Comissão Interministerial de Desenvolvimento Sustentável, as quais se encontram vinculadas ao MMA. A Comissão Interministerial de Mudança Global do Clima é composta por vários ministérios; o Fórum Brasileiro de Mudanças Climáticas tem apoio administrativo e os meios necessários à execução dos trabalhos providos pelo Ministério da Ciência e Tecnologia; o Comitê Interministerial sobre Mudança do Clima (CIM) conta com o apoio administrativo dos seus componentes.

Para uma melhor visualização da aplicação dos critérios de efetividade no âmbito interno referente às mudanças climáticas, segue quadro:

\begin{tabular}{|c|c|c|c|c|}
\hline & CRITERIOS & INTERNALIZANTES & ESPECIFICAS & EXEQUENTES \\
\hline \multirow[t]{7}{*}{ NORMATIVO } & $\begin{array}{l}\text { Entrada em vigor em tempo } \\
\text { razoável }\end{array}$ & Parcial & Negativo & Parcial \\
\hline & $\begin{array}{ll}\text { Correspondência } & \text { com } \\
\text { objetivo dos tratados } & \end{array}$ & Positivo & Positivo & Positivo \\
\hline & $\begin{array}{l}\text { Clareza no conteúdo das } \\
\text { obrigações }\end{array}$ & $\begin{array}{l}\text { Não existente nesse } \\
\text { conjunto de normas }\end{array}$ & $\begin{array}{l}\text { Não } \\
\text { aplicado }\end{array}$ & Parcial \\
\hline & Dispor de metas e métodos & $\begin{array}{l}\text { Não existente nesse } \\
\text { conjunto de normas }\end{array}$ & Parcial & Parcial \\
\hline & Completude & $\begin{array}{l}\text { Não existente nesse } \\
\text { conjunto de normas }\end{array}$ & Parcial & Não aplicado \\
\hline & $\begin{array}{l}\text { Conduzir à modificação no } \\
\text { comportamento humano }\end{array}$ & Positivo & Parcial & Parcial \\
\hline & $\begin{array}{l}\text { Tiver impacto só por meio } \\
\text { de sua própria existência }\end{array}$ & Positivo & Positivo & Positivo \\
\hline
\end{tabular}


ISSN 1981-3694

(DOI): $10.5902 / 1981369430027$

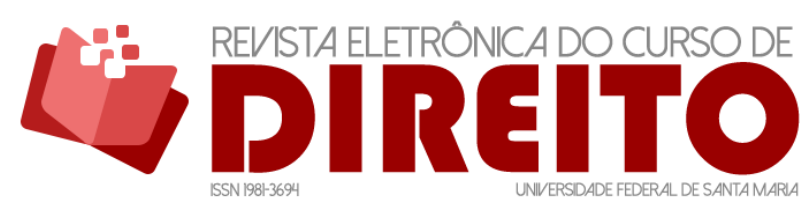

A INFLUÊNCIA DOS TRATADOS AMBIENTAIS MULTILATERAIS RELATIVOS AO CLIMA NA EFETIVIDADE DO DIREITO AMBIENTAL NO BRASIL

LAUREN LAUTENSCHLAGER MARCELO DIAS VARELLA

\begin{tabular}{|c|c|c|c|c|c|}
\hline & $\begin{array}{l}\text { Contiverem formas de } \\
\text { garantir a conformidade }\end{array}$ & $\begin{array}{l}\text { Não existente } \\
\text { conjunto de normas }\end{array}$ & nesse & Parcial & Parcial \\
\hline & $\begin{array}{l}\text { Contiverem meios para } \\
\text { promover o cumprimento }\end{array}$ & $\begin{array}{l}\text { Não existente } \\
\text { conjunto de normas }\end{array}$ & nesse & Parcial & Parcial \\
\hline \multirow[t]{4}{*}{ INSTITUCIONAL } & Criados em tempo razoável & \multicolumn{4}{|c|}{ Parcial } \\
\hline & $\begin{array}{l}\text { Correspondem com } 0 \\
\text { objetivo das normas criadas }\end{array}$ & \multicolumn{4}{|c|}{ Positivo } \\
\hline & $\begin{array}{l}\text { Forem completos, com todos } \\
\text { os órgãos necessários }\end{array}$ & \multicolumn{4}{|c|}{ Positivo } \\
\hline & $\begin{array}{l}\text { Tiverem } \\
\text { institucional }\end{array}$ & \multicolumn{4}{|c|}{ Parcial } \\
\hline
\end{tabular}

\section{CONCLUSÃO}

Em síntese, a aplicabilidade dos critérios entre as Convenções e os seus protocolos correspondentes pode ser analisada, primeiro, entre a Convenção de Viena sobre as substâncias que destroem a Camada de Ozônio e o seu Protocolo correspondente, qual seja, o Protocolo de Montreal; segundo, entre a Convenção das Nações Unidas sobre as mudanças climáticas e o seu Protocolo e Acordo correspondentes e, por fim, entre os grupos.

A observação conjunta da Convenção de Viena e do Protocolo de Montreal possibilita verificar que é própria de uma Convenção a parcialidade nos critérios materiais encontrados, embora isso não é, ou não deveria ser, característico dos textos apresentados na forma de Protocolos, os quais devem conter disposições mais específicas. O Protocolo inova ao trazer uma previsão de fundos no texto original do seu art. 13 e, mais ainda, com o estabelecimento de um mecanismo financeiro na nova redação do art. 10. Além disso, ele substitui o procedimento de solução de disputas pela aprovação de procedimentos e mecanismos institucionais para determinados casos de não cumprimento, conforme art. $8^{\circ}$.

A Convenção das Nações Unidas sobre as mudanças climáticas teve aplicação parcial nos critérios materiais de obrigações e meta, considerados normais em face da natureza do documento. O Protocolo de Quioto apresentou a mesma parcialidade dos mesmos critérios, o que não deveria ocorrer, por tratar-se de um Protocolo, além do critério formal de entrada em vigor em tempo razoável ter sido considerado negativo, o que causa estranheza, tendo em vista a atuação brasileira no cenário internacional. Ademais, foi estabelecida a necessária aprovação de procedimentos e mecanismos para determinar e tratar de casos de não cumprimento. Por fim, o Acordo de Paris, ao mesmo tempo em que apresenta a parcialidade nos critérios de 
obrigações e metas, traz novas formas de garantir a conformidade. Porém, não foi possível aplicar o critério formal de entrada em vigor, já que ele se encontra em fase de assinaturas.

No último documento internacional referente às mudanças climáticas, houve uma incisiva preocupação em "evitar colocar peso excessivo sobre as partes”, o que demonstra a delicadeza do assunto. Contudo, isso não pode ser entendido como uma permissão para que o teor das obrigações permaneça vago ou flexível, ou ainda que as metas sejam desprovidas de métodos, pois o texto internacional reflete na elaboração/execução das políticas públicas a serem realizadas no cenário interno.

Embora as circunstâncias para a criação do primeiro regime (SDCO) não tenham sido as mesmas na criação do segundo (mudanças climáticas), as duas Convenções sobre o clima apresentam idêntica aplicação de critérios. Além disso, é comum nesse tipo de documento a existência tanto de obrigações não claras, como metas desprovidas de método.

Com o objetivo de verificar em que medida as ações da Administração Pública Federal estão promovendo a adaptação dos diversos setores da economia brasileira aos cenários de mudanças do clima, o TCU deflagrou quatro auditorias no ano de $2008^{53}$, sendo elas: Amazônia Legal, Semiárido Brasileiro, Zonas Costeiras e Agropecuária. Porém, a crise econômica mundial ocorrida naquele ano transferiu as questões climáticas para um segundo plano. Além disso, a pouca evolução normativa e institucional referente ao tema na época concluiu por deficiências nas políticas nacionais. Dessa forma, espera-se uma nova auditoria do TCU em relação ao tema.

Comparando os documentos internacionais relativos às duas áreas do clima, é possível perceber que um ponto positivo da Convenção das Nações Unidas sobre as mudanças climáticas em relação à Convenção de Viena sobre as substâncias que destroem a Camada de Ozônio, já que aquela dispõe de melhor estrutura, estabelecendo de imediato dois órgãos subsidiários e um mecanismo financeiro. Em relação aos Protocolos, pode-se afirmar que os dois tiveram aplicação similar dos critérios, com exceção do Protocolo de Quioto que teve aplicação negativa do critério formal de entrada em vigor, o que não ocorreu no Protocolo de Montreal. Por fim, o Acordo de Paris diferencia-se dos demais no sentido desse critério não ter sido aplicado.

Observando o arranjo normativo-institucional sobre as SDCO, é possível perceber que o governo brasileiro não parece demonstrar devido cuidado quando da internalização dos documentos internacionais provenientes de emendas, já que apenas uma delas foi internalizada em tempo considerado razoável. Além disso, não houve a publicação de nenhuma norma específica quanto à temática das SDCO, o que pode prejudicar a dinâmica e a inter-relação

53 Por meio do TC 023.003/2008-9. 
entre as normas exequentes. Mesmo assim, pouco tempo após a elaboração dos documentos internacionais, a temática começou a ser regulamentada, havendo uma série de normas exequentes abordando o assunto. Tais normas tiveram autoria ora de ministérios estranhos ao meio ambiente, ora em conjunto com órgãos ambientais, ora ainda de forma exclusiva por órgãos ambientais.

Já no âmbito das instituições ambientais, foi possível perceber que as medidas tomadas no que tange às substâncias que destroem a Camada de Ozônio versam principalmente sobre a) a necessidade de realização de cadastramento; b) a proibição do uso e a restrição na importação de algumas substâncias; e c) a proibição na liberação de substâncias na atmosfera exigindo que elas sejam recolhidas mediante coleta apropriada e colocadas em recipientes adequados.

Ainda, é necessário ressaltar que, em 2012, foi instituído o Programa Brasileiro de Eliminação dos HCFCs - PBH no âmbito do Plano Nacional sobre Mudança do Clima, o que demonstra uma integração entre a temática das substâncias que destroem a Camada de Ozônio e a temática sobre as mudanças climáticas.

A maioria das normas exequentes referentes às SDCO entrou em vigor em tempo não razoável. Além disso, sobre o teor delas, pode-se notar que, quando existentes, as obrigações são claras, o que vai ao encontro com as obrigações claras do Protocolo de Montreal. As normas possuem correspondência com os documentos internacionais firmados, mas isso ocorre de forma restrita, ora com a disposição de algumas substâncias, ora ainda se aplicando a uma atividade. Não existe a estipulação de meta específica nas normas, nem mesmo a necessidade delas serem complementadas. Além disso, a proibição de algumas atividades leva a modificação do comportamento e a produção de impactos. Curiosamente, os meios de garantir a conformidade (dever de fiscalização) e promover o cumprimento (aplicação de sanções) que existem nas normas exequentes não são novidade, uma vez que ambos já estão expostos nas normas gerais de proteção ambiental.

Como pontos positivos, foi possível notar que algumas normas exequentes sobre as SDCO foram feitas logo em seguida aos documentos internacionais correspondentes, além delas serem atualizadas de acordo com os avanços daqueles. Porém, como pontos negativos desse conjunto de normas, pode-se observar que algumas medidas, como a de proibição na liberação de substâncias na atmosfera e devida recolha, bem como a integração das temáticas, ocorreu de forma tardia, uma vez que essa medida já poderia ter sido disposta em regulamentação anterior. Além disso, o constante recadastramento das empresas, por mais que busque a proteção ambiental, não a incentiva, já que sinaliza uma desordem no setor público. 
Em relação às Instituições, é importante mencionar que elas a) foram criadas concomitantemente às normas; b) são interministeriais, o que leva a uma maior possibilidade de vitalidade institucional; e c) são mistas, ora abordando um assunto geral e ora abordando um assunto específico.

Observando o arranjo normativo-institucional sobre as mudanças climáticas, é possível perceber que o Protocolo de Quioto não foi internalizado em tempo considerado razoável.

Foi observada a criação, de forma tardia, de duas normas específicas, uma delas criando um fundo e outra instituindo a Política Nacional sobre mudança do clima. Tais normas correspondem aos objetivos dos documentos internacionais firmados, mas não trazem em seu teor obrigações a serem cumpridas, não entrando em vigor em tempo razoável. As ações da Política criada devem reduzir a emissão de GEE, o que conduz a uma mudança comportamental e a uma produção de impactos. Por fim, a Política criada inova ao dispor de várias formas para garantir a conformidade, embora não contenha formas de promover o cumprimento.

As normas específicas foram devidamente regulamentadas pelas normas exequentes que, além dos Decretos que fazem parte desse grupo, dispõe ainda a IN 12/10. Poucas obrigações e metas foram observadas em face do teor dispositivo dos textos. Sobre isso, cabe salientar que o Decreto $n^{\circ} 7.390 / 10$ ao referir a obrigação de que, na elaboração dos planos plurianuais e Leis Orçamentárias Anuais, o Poder Executivo Federal deverá formular proposta de programas e ações que contemplem o disposto no Decreto (art. $9^{\circ}$ ), torna-a uma obrigação vaga já que não menciona quais programas e ações devem ser feitas. Todavia, isso vai ao encontro das obrigações consideradas não claras nos documentos internacionais referentes às mudanças climáticas, como, por exemplo, a obrigação vaga prevista no art. $4^{\circ}$, § $2^{\circ}$, da $C M C$, referente à obrigação de "adotar políticas nacionais e medidas correspondentes para mitigar a mudança do clima"; a obrigação de implementar e/ou aprimorar políticas e medidas "de acordo com suas circunstâncias nacionais", prevista no art. $2^{\circ}, \S 1^{\circ}$, “a”, do Protocolo de Quioto.

Além disso, embora os Decretos tenham entrado em vigor em tempo razoável, o mesmo não ocorreu com a Instrução Normativa n 12/10.

Como as normas exequentes são normas finais, o critério sobre a completude não pode ser aplicado a esse conjunto normativo.

Não foi possível encontrar formas de promover o cumprimento, mas, além da revisão, o Decreto $n^{\circ} 7.390 / 10$ exige que metodologias e mecanismos apropriados para aferir o cumprimento do compromisso nacional voluntário sejam adotados. 
Como pontos positivos desse conjunto normativo, pode-se notar a existência de normas específicas, diferentemente do que ocorreu com as SDCO. Tais normas organizam a temática, possibilitando o mesmo na edição das normas exequentes. Outra vantagem é que o Plano e o fundo nacional são considerados, dentre outros, como instrumentos da Política Nacional sobre a mudança do clima.

Porém, como pontos negativos, pode-se observar que as normas específicas foram feitas tardiamente, o que traz reflexo no desenvolvimento das normas exequentes. A preocupação com a mitigação dos impactos poderia ter sido regulamentada muito antes.

Em relação às Instituições é importante mencionar que: a) todas foram criadas antes da edição das normas específicas; b) a maioria delas possui caráter interministerial; c) a primeira instituição criada foi estabelecida no âmbito do desenvolvimento sustentável; e d) embora contenham competências diferentes, buscam auxiliar no desenvolvimento de ações sobre mudanças climáticas.

Por fim, é importante mencionar que o crescimento do Brasil no mercado de carbono foi promovido pelo arranjo normativo composto por normas internalizantes, específicas e exequentes, as quais decorreram dos documentos internacionais. Isso não significa, todavia, que tal crescimento não tenha sido impulsionado também pelos arranjos privados responsáveis pela efetividade do regime.

Comparando o arranjo normativo institucional das duas áreas que compõem o regime do clima, foi possível perceber que o primeiro possui mais normas (17), menor número de Instituições (2) quando comparadas ao segundo grupo, o qual apresenta uma menor quantidade de normas (9) e uma maior quantidade de Instituições (5).

0 resultado da aplicação dos critérios nas normas internalizantes mostrou-se o mesmo com a positividade de três critérios (correspondência, condução e impacto) e a parcialidade de um deles (vigência).

Não há como comparar o resultado da aplicação dos critérios nas normas específicas em face da inexistência delas no grupo das substâncias que destroem a Camada de Ozônio.

0 resultado da aplicação dos critérios nas normas exequentes ocorreu de forma diversa nos dois grupos. Em relação ao grupo das substâncias que destroem a Camada de Ozônio, um critério apresentou-se positivo em todas as normas (correspondência), um apresentou-se de forma negativa (metas), uma vez que não havia nenhuma meta específica, um (completude) não pode ser aplicado já que todas as normas daquele conjunto eram normas finais e os seis demais critérios tiveram aplicação parcial. Em relação ao grupo das mudanças climáticas, embora haja 
equivalência entre a aplicação positiva do critério sobre correspondência e não aplicabilidade do critério sobre completude, outro critério foi observado de forma positiva nesse conjunto de normas, o critério sobre a produção de impactos. Assim, da mesma forma, os seis demais tiveram aplicação parcial.

Chama-se atenção à aplicação positiva do critério de clareza nas obrigações das normas exequentes relativas às SDCO, as quais vão ao encontro das obrigações claras existentes no Protocolo de Montreal e à aplicação negativa desse critério em uma das normas exequentes relacionada às mudanças climáticas, a qual vai ao encontro das obrigações consideradas não claras nos documentos internacionais referentes às mudanças climáticas.

0 resultado da aplicação dos critérios às Instituições também se mostrou diferente no que tange à aplicação positiva e não aplicação deles, uma vez que três critérios foram observados de forma positiva nas Instituições sobre as SDCO (criação, correspondência e vitalidade) e um deles não pode ser aplicado (completude), já que os órgãos eram finais, ao passo que dois critérios foram observados de forma positiva nas Instituições sobre as mudanças climáticas (correspondência e completude) e os restantes foram aplicados de forma parcial.

Sinteticamente, de forma geral, o governo brasileiro atuou de forma tardia na temática do clima, seja com a internalização das normas internacionais, seja ainda na elaboração das normas específicas e/ou exequentes. Além disso, as primeiras normas e instituições criadas não ocorreram por meio de um órgão ambiental.

\section{REFERÊNCIAS}

AYALA, P. A. Direito e incerteza: a proteção jurídica das futuras gerações no Estado de direito ambiental. Florianópolis: UFSC, 2002. Dissertação (Mestrado em Direito), Universidade Federal de Santa Catarina, Florianópolis, 2002.

BENJAMIN, A. H. V. O Estado teatral e a implementação do direito ambiental. BDJur, Brasília, DF, 2010.

BIRNIE, P.; BOYLE, A. International Law and the environment. 2. ed. [S.l.]: Oxford, 1994.

BRYK, D. S. The Montreal Protocol and Recent Developments to Protect the Ozone Layer. In: Environmental Law Review, v. 15, p. 275, 1991.

CANOTILHO, J. J. G. Estado constitucional ecológico e democracia sustentada. In: LEITE, José Rubens Morato; FERREIRA, Heline Silvini; BORATTI, Larissa Verri (Org.). Estado de direito ambiental: tendências. 2. ed. Rio de Janeiro: Forense Universitária, 2010. p. 31-34. 
COLE, D. H. Climate Change and Collection Action. 2007. Disponível em: <http://papers.ssrn.com/sol3/papers.cfm?abstract_id=1069906>. Acesso em: 5 jan. 2016.

FALKNER, R. The Paris Agreement and the new logic of international climate politics. In: International Affairs, v. 92, n. 5, p. 1107-1125, 2016.

FENSTERSEIFER, T. Direitos fundamentais e proteção do ambiente: a dimensão ecológica da dignidade humana no marco jurídico-constitucional do Estado Socioambiental de Direito. Porto Alegre: Livraria do Advogado, 2008.

GAREAU, B. J. A critical review of the successful CFC phase-out versus the delayed methyl bromide phase-out in the Montreal Protocol. In: International Environmental Agreements: Politics, Law and Economics, v. 10, n. 3, p. 209-231, 2010.

KOSKENNIEMI, M. From apology to utopia. The structure of international legal argument. Cambridge: Cambridge University Press, 2006.

LEFF, E. Complexidade, Racionalidade Ambiental e Diálogo de Saberes. In: Revista Educação e Realidade, v. 34, n. 3, p. 17-24, set./dez. 2009.

LEITE, J. R. M. L. Sociedade de risco e Estado. In: CANOTILHO, J. J. C.; LEITE, J. R. M. Direito Constitucional ambiental brasileiro. 5. ed. São Paulo: Saraiva, 2012. p. 157-232.

LEITE, J. R. M.; CAETANO, M. A. Estado de direito ambiental e complexidade. In: PERALTA, Carlos E.; ALVARENGA, Luciano J.; AUGUSTIN, Sérgio (Org.). Direito e justiça ambiental: diálogos interdisciplinares sobre a crise ecológica. Caxias do Sul: Educs, 2014. p. 139-160.

LEWIS, S. L. The Paris Agreement has solved a troubling problem. In: Nature, v. 532, n. 7599, p. 283, 2016.

MALJEAN-DUBOIS, S. International environmental law. In: Seminário Jurídico Avançado, UNICEUB, Brasília, 2014.

MILARÉ, E. Direito do ambiente: a gestão ambiental em foco. 5. ed. São Paulo: Revista dos Tribunais, 2007.

MINISTÉRIO DO MEIO AMBIENTE. Ações brasileiras para a proteção da camada de Ozônio. Brasília: [S.n.], 2014.

MORRISON, F. L. The relationship of international, regional, and national environmental law. In: MORRISON, F. L., WOLFRUM, R. (Ed.). International, Regional, and National Environmental Law. Kluwer Law International. [S.l.]: Springer, 2000. p. 113-132.

NASSER, S. H. Direito internacional do meio ambiente, direito transformado, jus cogens e soft law. In: NASSER, S. H.; REI, F. (Org.). Direito internacional do meio ambiente. São Paulo: Atlas, 2006. p. 19-30.

OLIVEIRA, A. S. Tratamento diferenciado dos países em desenvolvimento e mudanças climáticas: perspectivas a partir do Acordo de Paris. 2017. Tese (Doutorado em Direito) Faculdade de Direito da Universidade Federal do Rio Grande do Sul, Porto Alegre, 2017. 
OST, F. Legal system between order and disorder. [S.l.]: Oxford University Press, 1994.

PALMER, G. The Implications of Climate Change for International Law Institutions. Transnat'l L. \& Contemp. Probs., v. 2, p. 205, 1992.

RAJAMANI, L. Ambition and differentiation in the 2015 Paris Agreement: Interpretative possibilities and underlying politics. In: International and Comparative Law Quarterly, v. 65, n. 2, p. 493-514, 2016.

SOARES, G. F. S. Curso de direito internacional público. São Paulo: Atlas, 2004.

SUNSTEIN, C. R. Montreal versus Kyoto: a tale of two protocols. John M. Olin Law \& Economics Working Paper $\mathrm{n}^{\circ} 302$ (2d series) and Public Law and Legal Theory Working Paper $\mathrm{n}^{\circ} 136$. Working Paper n 06-17. Chicago, 2006.

VARELLA, M. D. Internacionalização do Direito: direito internacional, globalização e complexidade. Brasília: UniCEUB, 2013.

VARELLA, M. D.; LAUTENSCHLAGER, L. Critérios de Efetividade na Proteção Ambiental. In: Revista do Programa de Pós-Graduação em Direito da UFC, v. 36.1, p. 295-329, jan./jun. 2016.

VIOLA, E. Evolução da mudança climática na agenda internacional e transição para uma economia de baixo carbono, 1990-2009. In: LEITE, J. R. M.; FERREIRA, H. S.; BORATTI, L. V. (Org.). Estado de direito ambiental: tendências. 2.ed. Rio de Janeiro: Forense Universitária, 2010. p. 47-94.

VIOLA, E. O regime internacional de mudança climática e o Brasil. In: RBCS, v. 17, n. 50, p. 25179, out. 2002.

VIOLA, E.; FRANCHINI, M. Climate Politics in Brazil: Public awareness, social transformations and emissions reduction. In: BAILEY, Ian; COMPSTON, Hugh (Ed.). Feeling the heat: The politics of climate policy in rapidly industrializing countries, 2012. p. 253-291.

WOLFRUM, R. The convention on biological diversity: using state jurisdiction as a means of ensuring compliance. In: WOLFRUM, R. (Ed.). Enforcing environmental standards: Economic mechanisms as viable means? [S.l.]: Springer, 1996. p. 374-393.

YOUNG, O. R. Teoria do regime e a busca de governança global. In: VARELLA, Marcelo D.; BARROS-PLATIAU, Ana Flavia (Org.). Proteção internacional do meio ambiente. Brasília: UNITAR, UNICEUB, UNB, 2009. v. 4. p. 220-235.

\section{COMO FAZER A REFERÊNCIA DO ARTIGO (ABNT):}

LAUTENSCHLAGER, Lauren; VARELLA, Marcelo Dias. A influência dos tratados ambientais multilaterais relativos ao clima na efetividade do direito ambiental no Brasil. Revista Eletrônica do Curso de Direito da UFSM, Santa Maria, RS, v. 13, n. 2, p. 722-753, ago. 2018. ISSN 1981-3694. Disponível em: <https://periodicos.ufsm.br/revistadireito/article/view/30027>. Acesso em: dia mês. ano. doi: http://dx.doi.org/10.5902/1981369430027. 